\title{
Energy contribution to Latin American NDCs: Analyzing sub-regional trends with a TIMES model
}

\author{
Sebastien POSTIC ${ }^{1,2}$, Sandrine SELOSSE ${ }^{1}$, Nadia MAÏZI ${ }^{1}$
}

\section{Introduction}

The most optimistic Representative Concentration Pathway (RCP 2.6) in the fifth IPCC Assessment Report predicts a $0.3^{\circ} \mathrm{C}$ to $1.7^{\circ} \mathrm{C}$ global mean temperature change in 2100 , putting natural species and systems at risk, possibly triggering large-scale irreversible natural damage, and strongly impacting human activities (IPCC, 2014). In Central and South America and the Caribbean, the latest estimates point to a 1.5\% to 5\% GDP loss by 2050 in the case of a $2.5^{\circ} \mathrm{C}$ global temperature increase (ECLAC, 2014).

On the other hand, the region represents a relevant share of global GHG emissions: $8.5 \%$ in 2010 (World Resources Institute, 2015), more than its share of the world's population (6.9\% in the same year). Brazil already ranks fourth in the world when it comes to national contributions to global warming (Matthews et al., 2014) and a strong increase in GHG emissions can be anticipated in the years to come throughout the region on a BAU basis (Carvallo et al., 2014; Fundación Bariloche, 2008; van Ruijven et al., 2015).

Quite logically, Central and South America and the Caribbean (CSA-C later on) thus have a relevant role to play in mitigating global emissions, and in global climate negotiations. Most countries in the region proposed Intended Nationally Determined Contributions (INDCs) as a prelude to the Paris Climate Conference in December 2015. An evolution of the Nationally Appropriate Mitigation Actions (NAMAs) encouraged after the Copenhagen Accord in 2009, INDCs provided a flexible framework within which non-Annex I countries could pledge voluntary actions aimed at deviating from BAU emissions (Sharma and Desgain, 2014). As an outcome of COP21, these INDCs should automatically transform into NDCs (Nationally Determined Contributions) with the ratification of the Paris Agreement, unless a country decides otherwise. All Parties have not yet ratified the Paris Agreement as we write these lines; however, only two Central American countries (Belize and Panama) revised their initial submission ${ }^{3}$ as of Sep $22^{\text {nd }}, 2016$; we will thus consider in the framework of this paper that all INDCs will eventually convert into actual NDCs ${ }^{4}$.

The energy sector shows promising potential to achieve GHG emissions mitigation worldwide (Akimoto et al., 2010) and CSA-C NDCs consider it extensively. However, this potential may remain below world averages (Bassi and Baer, 2009; Borba et al., 2012; Di Sbroiavacca et al., 2015), because of an already-renewable energy mix, fast energy growth -the electrification rate jumped from 75\% in 2009 to around 90\% in 2012 in Peru and Bolivia (CIER, 2013, 2011) - and the use of energy as a tool for domestic and international policy (Colgan, 2014).

Given CSA-C's regional specificities, what can be the contribution of its energy sector to the fight against climate change? We present in section 2 the past (NAMAs) and current (NDCs) pledges proposed by CSA-C's countries to the United Nations Framework Convention on Climate Change (UNFCCC), and derive five contrasted policy scenarios. In

\footnotetext{
${ }^{1}$ MINES ParisTech, PSL - Research University, CMA - Centre de Mathématiques Appliquées

${ }^{2}$ Corresponding author. Email: sebastien.postic@mines-paristech.fr

${ }^{3}$ These two countries submitted in fact an NDC while ratifying the Agreement, without having previously proposed an INDC.

${ }^{4} \mathrm{~A}$ review of national NAMA and NDC submissions in CSA-C is given in Appendix A. For an up-to-date compilation of these pledges, the reader may refer to the UNFCCC website.
} 
section 3, we study these scenarios' impact, focusing on the energy sector, by means of a bottom-up energy prospective model.

We start by considering the specific case of the power mix then expand our study to the whole total primary energy supply, underlining the added value of NDCs in driving the energy transition in CSA-C. We also consider the links between the Afforestation, Forestry and Other Land-Use (AFOLU) sector, the energy sector and the fight against climate change in CSA-C, then conclude.

Let us highlight the fact that Mexico is not part of our geographical scope, as will be detailed in section 2.1. However, the CLIMACAP multi-model comparison exercise which ended in December 2015 (van der Zwaan et al., 2016) proposed an extensive analysis of energy and climate change mitigation in South America, including one specific analysis for Mexico (Veysey et al., 2016). To our knowledge, our work is the first analysis of this kind conducted with a dedicated regional tool, yet our results mostly complement and support the findings of the CLIMACAP project for CSA-C.

\section{Methods and scenarios}

\subsection{The T-ALyC model}

The results presented and discussed in this paper are based on the T-ALYC model, standing for TIMES para América Latina y el Caribe (TIMES for Latin America and the Caribbean). T-ALYC is a bottom-up, linear representation of CSAC's energy system, inherited from the TIMES Integrated Assessment Model TIAM (Loulou and Labriet, 2008; Ricci and Selosse, 2013; Syri et al., 2008); the full model is presented in detail in (Postic, 2015). T-ALyC describes the whole regional energy system from resource extraction to end-use energy demands, in what is called the Reference Energy System (RES). The RES, as displayed in Figure 1, includes both existing and potential new technologies, that is, a portfolio of some thousands processes described through their physical features (efficiency, investment costs, O\&M costs, life, emission factors, etc.) and the energy commodities they consume/produce. The model then optimizes the investment in, and operation of, energy processes so as to satisfy an exogenous energy service demand at the lowest possible cost. Demand satisfaction is subject to resource constraints (resource availability, extraction cost), technical constraints (physical balances, availability factors, etc.) and non-technical constraints (market penetration limits, policy scenarios, environmental specifications, etc.). For more information on the TIMES paradigm and its implementation, please refer to (Loulou et al., 2005). The outputs of our model are the evolution and final structure of the energy system, individual investment and operation costs for each modeled technology, process-related and fuel-related emissions and energy trade flows between model regions and with the rest of the world. 


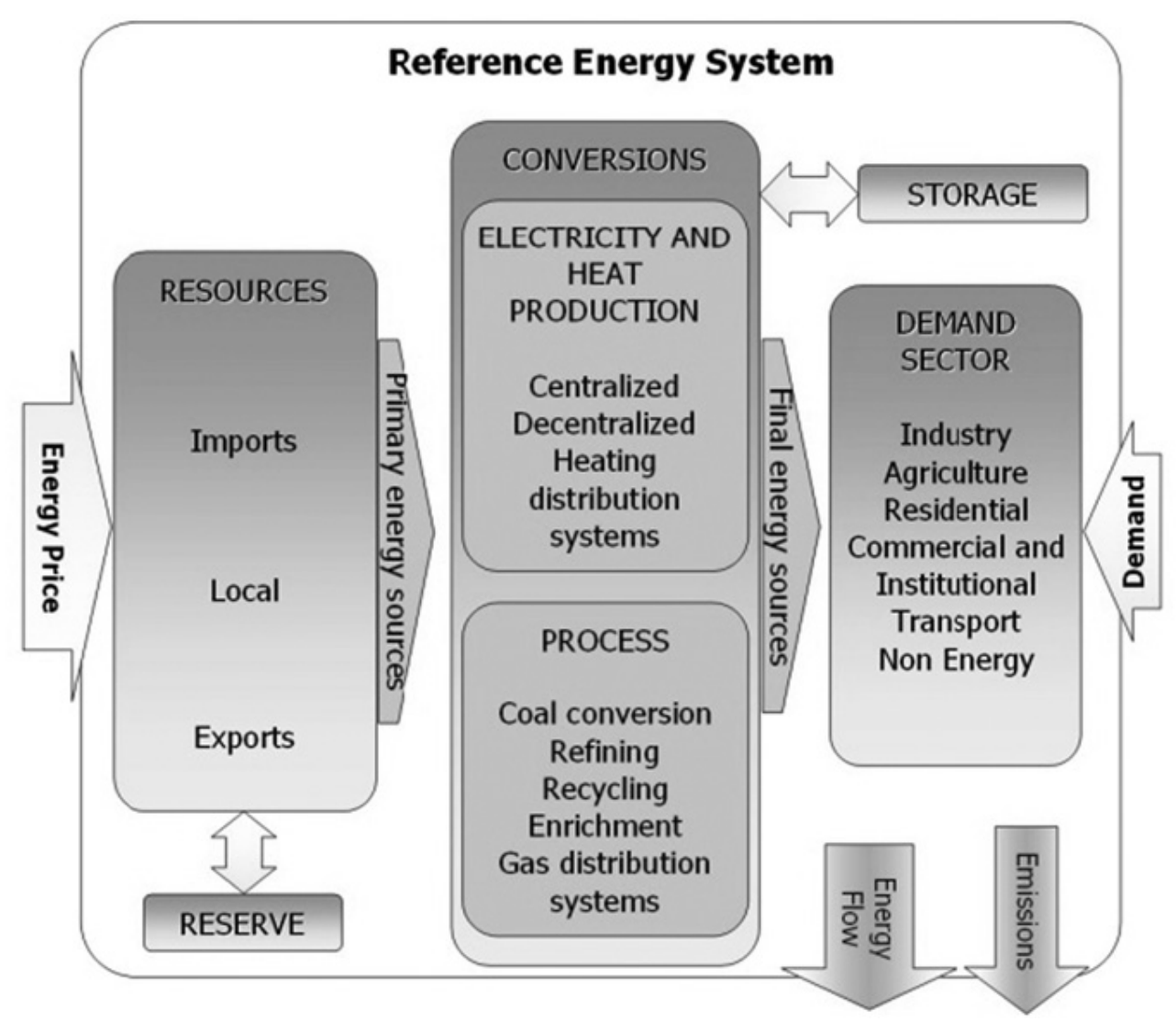

Figure 1: Synthetic view of a TIMES Reference Energy System (Ricci and Selosse, 2013)

T-ALyC considers the entire Latin America and the Caribbean region, excluding Mexico. This geographical scope corresponds that of the so-called "Central and South America" in TIAM-FR, allowing for result comparison and limited model coupling between the two models. T-ALyC relies on an ad hoc disaggregation of the area into 10 subregions (cf. Table 1 and Figure 3 ) to address region-specific issues including the role of hydropower and interrogations about its future development, the current and future role of biofuels in the energy mix, challenges, opportunities and time dynamics of regional integration, climate and energy interactions, etc. The base year for model projections is 2010 and the end horizon is 2050. This time span is divided into 7 time periods of unequal length, centered around 2010, 2012, 2015, 2020, 2030, 2040 and 2050.

\begin{tabular}{c|l}
\hline Region name & \multicolumn{1}{c}{ Region description } \\
\hline $\boldsymbol{A N D}$ & Peru, Ecuador \\
$\boldsymbol{A} \boldsymbol{R} \boldsymbol{G}$ & Argentina \\
$\boldsymbol{B P U}$ & Bolivia, Paraguay, Uruguay \\
$\boldsymbol{B S E}$ & Brazil - South and Southeast administrative regions \\
$\boldsymbol{B W C}$ & Brazil - North, Northeast and Center administrative regions \\
$\boldsymbol{C H L}$ & Chile \\
$\mathbf{C O L}$ & Colombia \\
$\boldsymbol{C Y C}$ & Central America and the Caribbean \\
$\mathbf{S U G}$ & Suriname, Guyana, French Guyana \\
$\mathbf{V E N}$ & Venezuela \\
\hline
\end{tabular}

Table 1: T-ALyC geographical disaggregation

Energy potentials and end-use demands are calibrated based on a wide variety of sources, including (ALACERO, 2013; Garcés et al., 2012; Global Energy Observatory, 2013; Hoornweg and Bhada-Tata, 2012; IEA, 2014; IER, 2006; IMF, 2014; Riegelhaupt and Chalico, 2009; Smeets et al., 2007; UNDESA, 2012; UNEP, 2012; US-EIA, 2014; World Nuclear Association, 2008) and national sources. Base-year energy service demands are described in useful energy 
service units (e.g. ton-km for freight transportation) then projected through 2050 using exogenous projections for macroeconomic drivers such as GDP, population, number of households, etc. The full description of T-ALyC end-use demands is too large to be specified here; however, the interested reader may refer to (Postic, 2015) for a complete description of these demands and their drivers up to 2050. For this study, prices for energy commodity trade with the rest of the world are based on TIAM endogenous trade prices for its CSA-C region.

\subsection{GHG emissions and mitigation options in T-ALyC}

The emission structure in CSA-C is quite different from the rest of the world. Brazil's national emission inventory reported, in 2016, GHG emissions from the energy sector that amounted to only $29 \%$ of total national emissions for 2010 (MCTI, 2016). By comparison, energy emissions for the European Union at the same date accounted for $80 \%$ of total emissions ${ }^{5}$ (European Commission, 2014). This is mainly due to Agriculture, Forestry and Other Land-Use (AFOLU) emissions: while in 2010 the Land-use, Land Use Change and Forestry sector in Europe was a net sink at $296 \mathrm{Mt} \mathrm{CO} 2 \mathrm{eq}$, the same sector in Brazil contributed up to $756 \mathrm{Mt} \mathrm{CO}_{2}$ eq to national emissions. AFOLU emissions are thus not explicitly energy-related, yet they can impact the energy system through climate pledges. Faced with an emission-reduction objective, planners could choose to spend the money either on emission reductions in the energy-production sector, or on dedicated non-energy measures in e.g. the AFOLU or waste sectors. Available options in AFOLU include curbing deforestation, reforestation measures (re-establishment of a forest depleted by deforestation) and afforestation (creation of new forest areas). See (Smith et al., 2014) for a complete description of AFOLU's stakes in relation to global warming.

Non-energy emissions are taken into account in T-ALyC in an exogenous fashion through dedicated emission technologies, as described on Figure 2 below. The activity of these technologies is calibrated based on national communications to the UNFCCC; model values are available in (Postic, 2015). The three main emission sources are $\mathrm{CO}_{2}$ from Land-Use, Land-Use Change and Forestry (LULUCF), $\mathrm{N}_{2} \mathrm{O}$ from agriculture (including manure) and $\mathrm{CH}_{4}$ emissions related to biomass burning and enteric fermentation (cattle ranching). BWC and AND were the main emitters among T-ALyC's regions in 2010, with 781.5 and $478.7 \mathrm{MtCO}_{2}$ eq emitted respectively.

\footnotetext{
${ }^{5}$ Excluding AFOLU which is actually a sink rather than a source of $\mathrm{CO}_{2}$ emissions in Europe.
} 


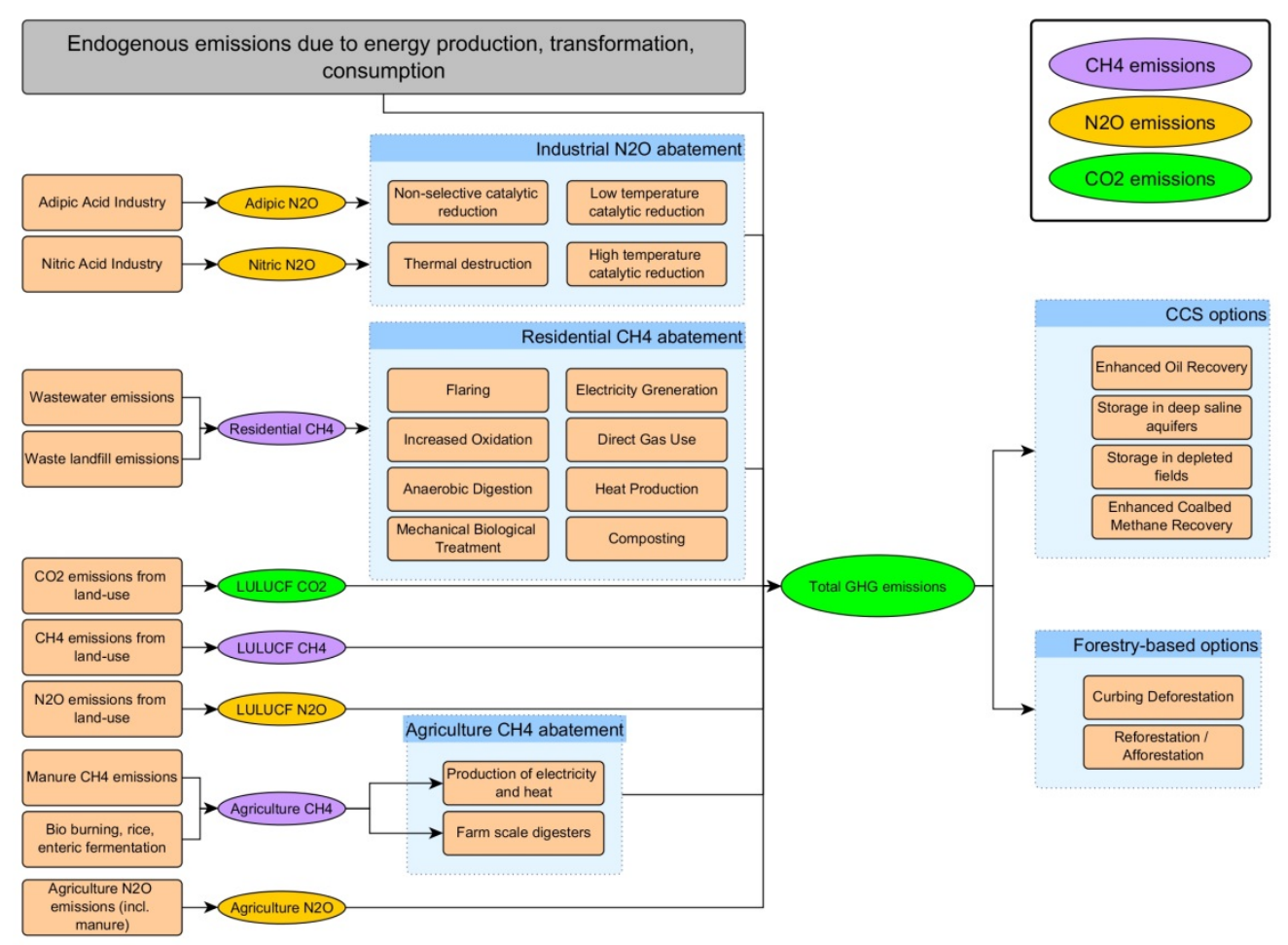

Figure 2: Accounting for non-energy GHG sources and sinks in T-ALyC

T-ALyC also accounts for non-energy mitigation options through dedicated abatement technologies. While some mitigation measures directly reduce GHG emissions (e.g. thermal destruction of $\mathrm{N}_{2} \mathrm{O}$ emissions from the Nitric Acid Industry, or the fight against deforestation), some mitigation options are only indirectly related to emission values e.g. reforestation- or totally unrelated -e.g. deep aquifer storage. In the case of forestry-based abatement, the options and policies available were modeled with six virtual technologies implementing six cost steps and associated maximal emission reduction potentials. These costs were calibrated on external sources such as (Asner et al., 2014; Elberg Nielsen et al., 2014; Gonzalez Arenas et al., 2011; MAE, 2011; MCT, 2010; MINAM, 2010; Ministerio de Ambiente de Colombia, 2012; Ministerio del Ambiente del Ecuador, 2012; MMA, 2011; MMAyA, 2009; MVOTMA, 2010; Nepstad et al., 2009; SAyDS, 2007; SEAM, 2011; Smith et al., 2014). We separate measures related to the fight against deforestation, calibrated on national baseline projections for deforestation, from afforestation-related measures, whose potential is linked to the available surface area. This area depends on the amount of forest-free land, and on the competition between afforestation and agriculture or other productive activities.

For non-forestry based options, we used TIAM costs and potentials (Ricci and Selosse, 2013) and regionalized the latter based on T-ALyC's sub-regional fossil fuel extraction potentials and surface areas. For all other options, we used TIAM costs and potentials (Ricci and Selosse, 2013) and regionalized the latter based on the T-ALyC regions' extraction potentials and surface areas. The potentials and costs of carbon storage technologies are detailed in Table 2 for the whole region; sub-regional detail can be found in (Postic, 2015). CCS costs include transportation.

\begin{tabular}{l|c|c}
\hline \multicolumn{1}{c|}{ Storage option } & Potential $\left(\mathbf{M t C O}_{2} \mathbf{e q}\right)$ & Cost $\left(\mathbf{\$} / \mathbf{t C O}_{2}\right)$ \\
\hline Deep saline aquifers (onshore) & 23,414 & 5.7 \\
\hline Deep saline aquifers (offshore) & 6,886 & 9.3 \\
Enhanced Oil Recovery and depleted fields injection (onshore) & 46,200 & 5.1 \\
Enhanced Oil Recovery and depleted fields injection (offshore) & 35,100 & 8.2 \\
Enhanced coalbed methane recovery & 2,000 & 4.9 \\
Curbing deforestation - Step 1 & 29,168 & 3 \\
Curbing deforestation - Step 2 & 5,209 & 6 \\
Curbing deforestation - Step 3 & 3,125 & 55 \\
\hline
\end{tabular}




\begin{tabular}{l|l|l}
\hline Afforestation - Step 1 & 5,822 & 10 \\
Afforestation - Step 2 & 3,639 & 25 \\
Afforestation - Step 3 & 3,639 & 45 \\
\hline
\end{tabular}

Table 2: Overall potential (MtCO2eq) and average costs of carbon storage technologies $\left(\mathbf{\$ 2 0 0 0 / \mathrm { tCO } _ { 2 } )}\right.$

A third option for emission mitigation in the energy sector, namely energy efficiency measures, is only partially described in T-ALyC. Our description of a demand for exogenous energy services, not energy itself, allows us accounting for the efficiency of end-use energy devices (trucks, chillers, dishwashers, etc.). However, the level of detail of this description is quite crude as T-ALyC embarks a description of the whole energy chain, and energy efficiency measures leading to a decrease in final demand itself must be considered in an exogenous manner in this model (e.g. using low-demand scenarios) ${ }^{6}$.

\subsection{Climate scenarios}

In order to assess the impact of NAMAs and the additional modifications introduced by the NDCs, five climate policy scenarios were designed: 'Business-As-Usual' (BAU), 'Nationally Adapted Mitigation Actions' (NAMAs), 'Unilateral NDCs, based on national BAUs' (Uni_Nat), 'Conditional NDCs, based on national BAUs' (Cond_Nat), and 'Conditional NDCs, based on T-ALyCBAU' (Cond_TALYC). Table 3 gathers the main emission bounds in our four climate scenarios.

The Business-As-Usual scenario considers that no climate pledge is taken by any country. It allows presenting the key energy determinants of the continent, and serves as a comparison point for climate pledge scenarios. This BusinessAs-Usual scenario is also used to calibrate the NAMAs scenario, since most countries did not provide national BAU projections with their NAMA commitments. T-ALyC's BAU emissions can differ substantially from national projections: Chile and Argentina exhibit BAU emissions 30\% to $40 \%$ below national scenarios in T-ALyC's projections. The main reason for this is the quick decarbonization of electricity production in T-ALyC in these two regions: existing fossil-based capacity that finishes its technical life is replaced by renewable energy production sources, mainly hydropower, with very low GHG emissions. This decarbonization trend is not envisioned in national BAU projections. For Chile, Carvallo et al. (2014) showed that a decarbonization scenario was only very slightly costlier than their highly emissive BAU, making a low-emissive BAU in T-ALyC easily conceivable. The Argentine case could be more argued on, as results in (Di Sbroiavacca et al., 2016) tend to diverge on this question: while high carbon prices do not deviate Argentina's BAU from its high-emission pathway in LEAP, GCAM and TIAM-ECN emissions are indeed quite sensitive to $\mathrm{CO}_{2}$ prices' variations. For Brazil and the Andean region, on the other hand, BAU GHG emissions in T-ALyC are fairly in line with national projections, with less than $5 \%$ difference between the two figures; Colombia also presents similar values, with less than $10 \%$ difference between national and T-ALyC's projections.

The Nationally Adapted Mitigation Actions scenario considers that national NAMAs as described in Table 4 (in the Appendix) are implemented in Brazil, Chile, Colombia and Peru, plus a 30\% deforestation reduction in Ecuador. For Brazil, T-ALyC's target takes into account the fact that the fight against deforestation improved dramatically between 2005 -when the first pledge was made- and 2010 -T-ALyC's base year-. Also, Brazil's constraint is written as an overall cap for the joint emissions of the two-region Brazil, meaning that the choice of where to reduce emissions is left to the model. Both Brazil and Chile's targets are extrapolated to $40 \%$ below BAU in 2050. On the other hand, pledges for Colombia, Peru and Ecuador do not become stronger between 2020 and 2050. National voluntary policies that did not lead to a NAMA pledge to the UNFCCC were not included.

The Unilateral NDCs, based on national BAUs scenario considers all national unilateral contributions, i.e. the minimal pledges offered by UNFCCC Parties in the absence of international support. As T-ALyC 10-region disaggregation does not ever go all the way to country-scale modeling, national pledges were aggregated into sub-regional emission

\footnotetext{
${ }^{6}$ The TIMES paradigm allows modeling elastic demands, which could be a good approximation to modeling the cost of demandside mitigation policies. Since data to calibrate such elasticities was scarce, we stuck to inelastic demands in this work.
} 
bounds, as per Table 3. When BAU information was available, these bounds translate BAU-based targets, intensitybased targets and absolute emission reductions into absolute, all-encompassing maximum emissions. The only exception is Brazil, which provided its own absolute target for national emissions. All targets are extrapolated with constant values through 2050, since no information was available past 2030 . This optimistic assumption has the merit of being straightforward and uniform, and of giving an insight on how the continent would react under increasing climate pressure over the 20-year period following the NDC horizon.

The Conditional NDCs, based on national BAUs scenario reflects national contributions if international help (financial, technological transfers etc.) is available. When a country (e.g. Brazil) has not specified a conditional target, this scenario considers its unilateral contribution. As for Uni_Nat, 2030 targets are extrapolated as constants until 2050.

As mentioned above, BAU GHG emissions in T-ALyC can differ substantially from national BAU projections, especially for Chile and Argentina, which may distort the effect of national pledges on the energy mix: if emissions are already low in T-ALyC'S BAU, an upper bound based on national projections will have less impact. The Conditional NDCs, based on T-ALYC BAU scenario allows us to assess the gap between these two acceptations of 'below BAU reductions'. Plus, since T-ALyC'S BAU is less emissive than national projected pathways in most model regions, Cond_TALYC gives us a vision of the potential impacts of stringent reduction pledges in CSA-C. Like the two previous scenarios, Cond_TALYC uses constant GHG bounds between 2030 and 2050.

\begin{tabular}{|c|c|c|c|c|c|}
\hline Region & NAMAs & $\begin{array}{l}\text { Target Year } \\
\text { (NDCs) }\end{array}$ & Uni_Nat & Cond_Nat & Cond_TALyC \\
\hline AND & $\begin{array}{l}\text { 30\% RNW in Final NRJ } \\
\text { Deforestation drop }\end{array}$ & 2025 & $333 \mathrm{MtCO}_{2} \mathrm{eq}$ & $277 \mathrm{MtCO}_{2} \mathrm{eq}$ & $283 \mathrm{MtCO}_{2} \mathrm{eq}$ \\
\hline ARG & - & 2030 & $570 \mathrm{MtCO}_{2} \mathrm{eq}$ & $469 \mathrm{MtCO}_{2} \mathrm{eq}$ & $293 \mathrm{MtCO}_{2} \mathrm{eq}$ \\
\hline BPU & - & 2025 & $310 \mathrm{MtCO}_{2} \mathrm{eq}$ & $276 \mathrm{MtCO}_{2} \mathrm{eq}$ & $276 \mathrm{MtCO}_{2} \mathrm{eq}$ \\
\hline $\begin{array}{l}\text { BSE- } \\
\text { BWC }\end{array}$ & $\begin{array}{l}1,414 \mathrm{MtCO}_{2} \mathrm{eq}(2020) \\
1,542 \mathrm{MtCO}_{2} \mathrm{eq}(2050)\end{array}$ & 2030 & $1,200 \mathrm{MtCO}_{2} \mathrm{eq}$ & $1,200 \mathrm{MtCO}_{2} \mathrm{eq}$ & $1,200 \mathrm{MtCO}_{2} \mathrm{eq}$ \\
\hline CHL & $\begin{array}{l}-20 \% \text { GHG }(2020) \\
-40 \% \text { GHG }(2050)\end{array}$ & 2030 & $158 \mathrm{MtCO}_{2} \mathrm{eq}$ & $124 \mathrm{MtCO}_{2} \mathrm{eq}$ & $84 \mathrm{MtCO}_{2} \mathrm{eq}$ \\
\hline COL & $\begin{array}{c}77 \% \text { RNW in ELC } \\
20 \% \text { biofuels in TRA }\end{array}$ & 2030 & $268 \mathrm{MtCO}_{2} \mathrm{eq}$ & $235 \mathrm{MtCO}_{2} \mathrm{eq}$ & $214 \mathrm{MtCO}_{2} \mathrm{eq}$ \\
\hline CYC & - & 2030 & $304 \mathrm{MtCO}_{2} \mathrm{eq}$ & $270 \mathrm{MtCO}_{2} \mathrm{eq}$ & $270 \mathrm{MtCO}_{2} \mathrm{eq}$ \\
\hline SUG & - & - & - & - & - \\
\hline VEN & - & - & - & - & - \\
\hline
\end{tabular}

\section{Results and discussion: Impact of climate pledges on the Energy sector}

In this part we investigate the results of T-ALyC's calculations. Figure 3 offers an overview of CSA-C's main GHG emissions by region and by source, and the impact of national contributions on these emissions. As mentioned in paragraph 2.2, AFOLU is the main source for GHG emissions on the continent, followed by upstream and transportation. Brazil is CSA-C's largest emitter; its BWC region alone emits more than any other model region, mostly due to Amazon deforestation. These emissions are fairly reduced in the Cond_TALyC scenario, as shown on

\footnotetext{
${ }^{7}$ Deforestation absolute target cumulating the effect of $0 \%$ net deforestation in Peru, and $30 \%$ reduction of deforestation in Ecuador.

${ }^{8}$ Venezuela's targets are reported in Annex I, yet are not used in this study; the country currently faces a strong political and socio-economic crisis which makes its long-term behavior hardly predictable, and its INDC was submitted after the calculations for this work were made.
} 
the right of Figure 3. The overall impacts of CSA-C'S NDCs and NAMAs are further detailed in paragraph 3.1. Paragraph 3.2 focuses on the impact of climate pledges on the energy sector, while paragraph 3.3 investigates the changes happening to primary energy supply. Last, paragraph 3.4 details the role of CSA-C's non-energy emissions and mitigation options.
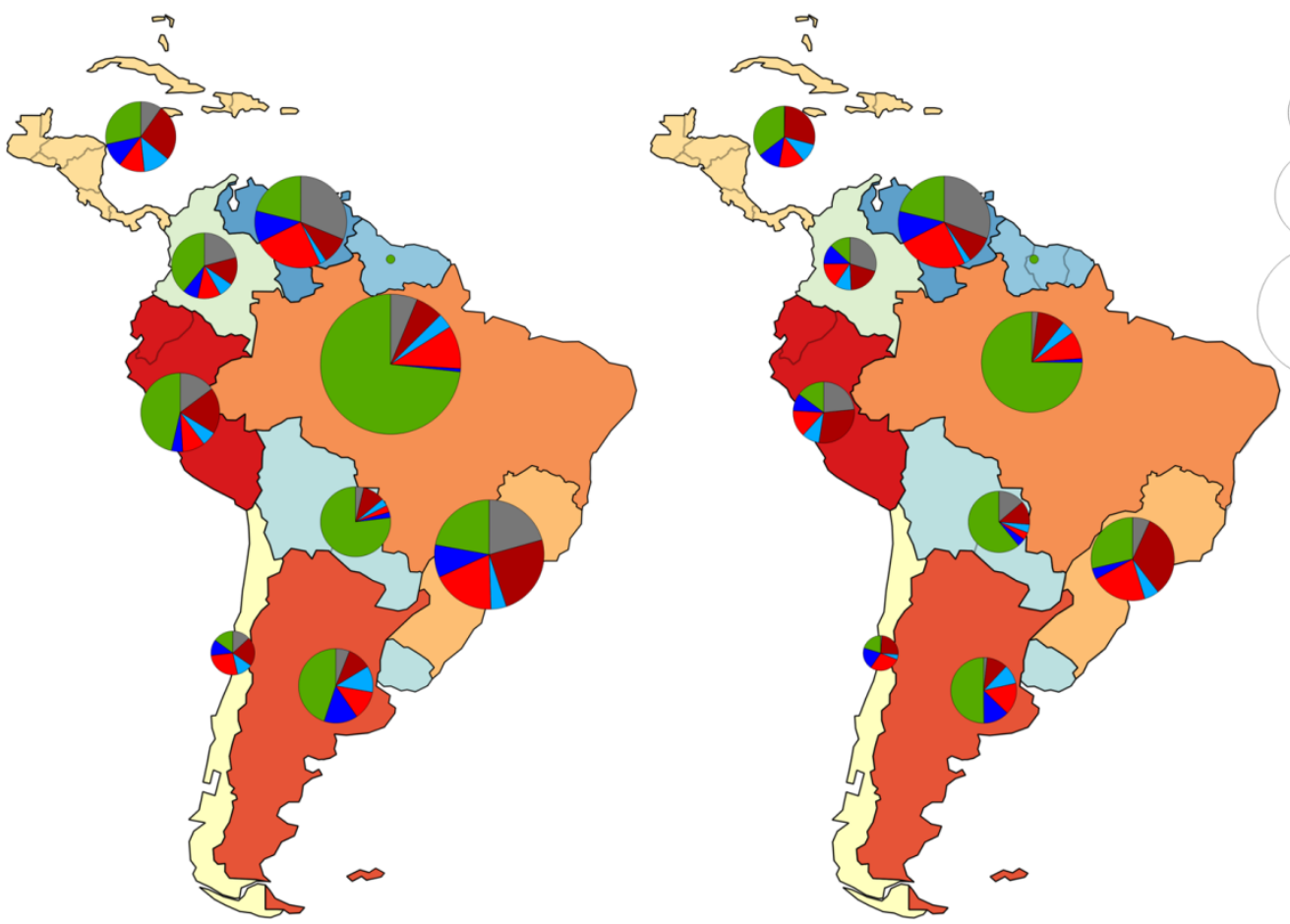

$300 \mathrm{MtCO} e \mathrm{eq}$

$600 \mathrm{MtCO} 2 \mathrm{eq}$

$1,200 \mathrm{MtCO}$ eq

Figure 3 : CSA-C's GHG emissions in 2030 under BAU (left) and Cond_TALyC (right) scenarios

\subsection{Impact of climate pledges on the energy sector: NAMAs vs. NDCs}

Figure 4 shows the regional impact of climate scenarios in terms of emission reductions. The NAMAs scenario results in emissions that are $24.6 \%$ below $B A U$ levels in 2030 ( $4.2 \mathrm{GtCO}_{2}$ eq instead of $5.6 \mathrm{GtCO}_{2} \mathrm{eq}$ ). However 2050 emission figures stand quite above 2010 levels, and the post-2020 trend in emissions increase is not quite different form business-as-usual. On the other hand, 2050 emissions are below 2010 levels in the Cond_Nat and Cond_TALyC scenarios, with emissions reductions up to $40.6 \%$ below BAU levels. Due to constant past-2030 GHG bounds in most model regions, T-ALyC's emissions also nearly stop increasing from 2030 on: the year-on-year increase in regional emissions between 2030 and 2050 drops from $40.7 \mathrm{MtCO}_{2} \mathrm{eq} / \mathrm{yr}$ in $B A U$ down to $4.0 \mathrm{MtCO}_{2} \mathrm{eq} / \mathrm{yr}$ in Cond_TALyC.

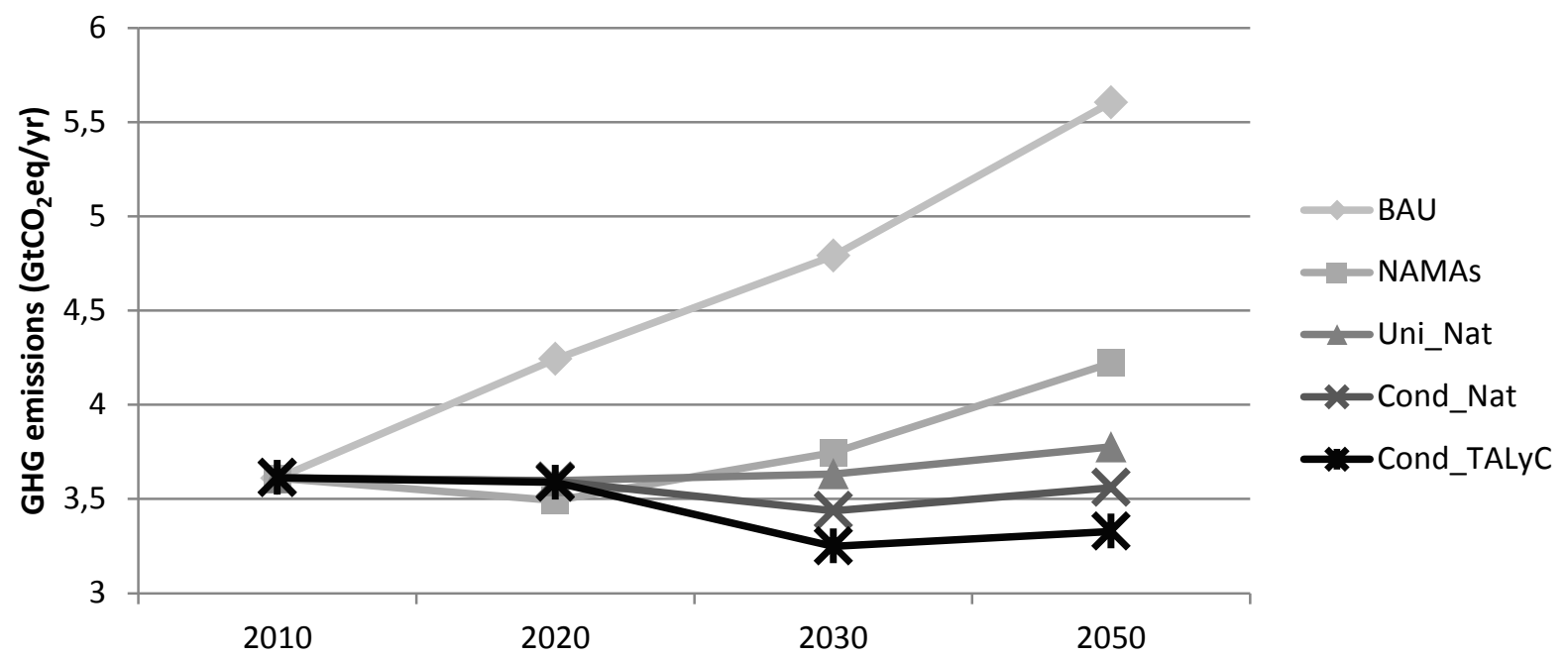

Figure 4: GHG emissions in CSA-C under BAU, NAMA and NDC conditions Page 8 
The dynamics presented on Figure 4 are far from homogeneous across the continent:

- In most cases, by 2030 NDCs lead to stronger emissions reductions than NAMAs. For Brazil, this drop is less significant than e.g. Colombia, BPU or Central America in relative terms; however, given the country's size, it still accounts for more than one third of the regional emissions decrease between the NAMAs and Cond_TALYC scenarios in 2030. The exception is the Andean region: Peru had ambitious NAMAs given its high deforestation rates. The country had not quantified the overall impact of its pledges, but independent academics estimated that the measures should lead to a 41\% GHG reduction compared to BAU (Hof et al., 2013). Peru's NDC, however, aims at a $30 \%$ emissions reduction below BAU at best.

- In all regions save BPU, emissions under the Cond_TALYC scenario are lower in 2030 than in 2010; and Uni_Nat emissions also come close to or drop below 2010 levels. In BPU, however, even the 20\% reduction committed to in the Cond_TALYC scenario is not sufficient to offset the region's strong growth of $B A U$ emissions.

- Last, the Uni_Nat and Cond_Nat scenarios for Argentina deviate very little from BAU projections; only the Cond_TALYC scenario results in effective emission reductions. This is in line with our BAU findings mentioned in section 2.3: the emissions reductions proposed by Argentina already occur under a no-policy framework in T-ALyC's representation. Chile presents similar results.

The cost of mitigation actions for the productive sectors described by T-ALyC ranges from $0.2 \%$ (NAMAs) to $0.8 \%$ (Cond_TALYC) over BAU costs in 2050. These figures are quite low compared with the $1.5 \%-5 \%$ GDP potential loss due to climate change effects as assessed by (ECLAC, 2014), highlighting the interest of mitigation actions against a climate strategy focusing only on adaptation. It is also worth noting that our stringent climate scenario is actually less expensive than BAU for the AND and BPU regions (by $0.2 \%$ ) in 2050. On the other hand, additional costs of mitigation measures can rise up to $6 \%$ over BAU cost in Chile, where they are found to be most expensive; again, this result is in line with the fact that Chile already decarbonizes it energy mix under BAU conditions in T-ALyC; as a consequence, additional efforts prove costlier than in other CSA-C's regions.

\subsection{Impact of climate pledges on the electricity sector: the weight of Southeast Brazil}

In 2012, CSA-C already boasted a highly renewable electricity mix, with more than $60 \%$ of hydro-sourced electricity (CIER, 2013). The remaining electricity production was mainly made up of fossil fuels (gas, oil and coal) and nuclear power. As shown on Figure 5, electricity generation is bound to more than double between 2010 and 2050, reflecting the region's forecasted strong growth. Our results show that this $132 \%$ increase in electricity generation goes hand in hand with a sharp drop in the share of fossils and nuclear between 2010 and 2050. Similarly, while hydro production keeps increasing in absolute terms - from 677 TWh in 2010 to 1,728 TWh in 2050, its share stabilizes at around $70 \%$ of all electricity production, even dropping slightly from $74 \%$ in 2030 to $72 \%$ in 2050 . The production gap is filled mainly by wind- and solar-based electricity production. 


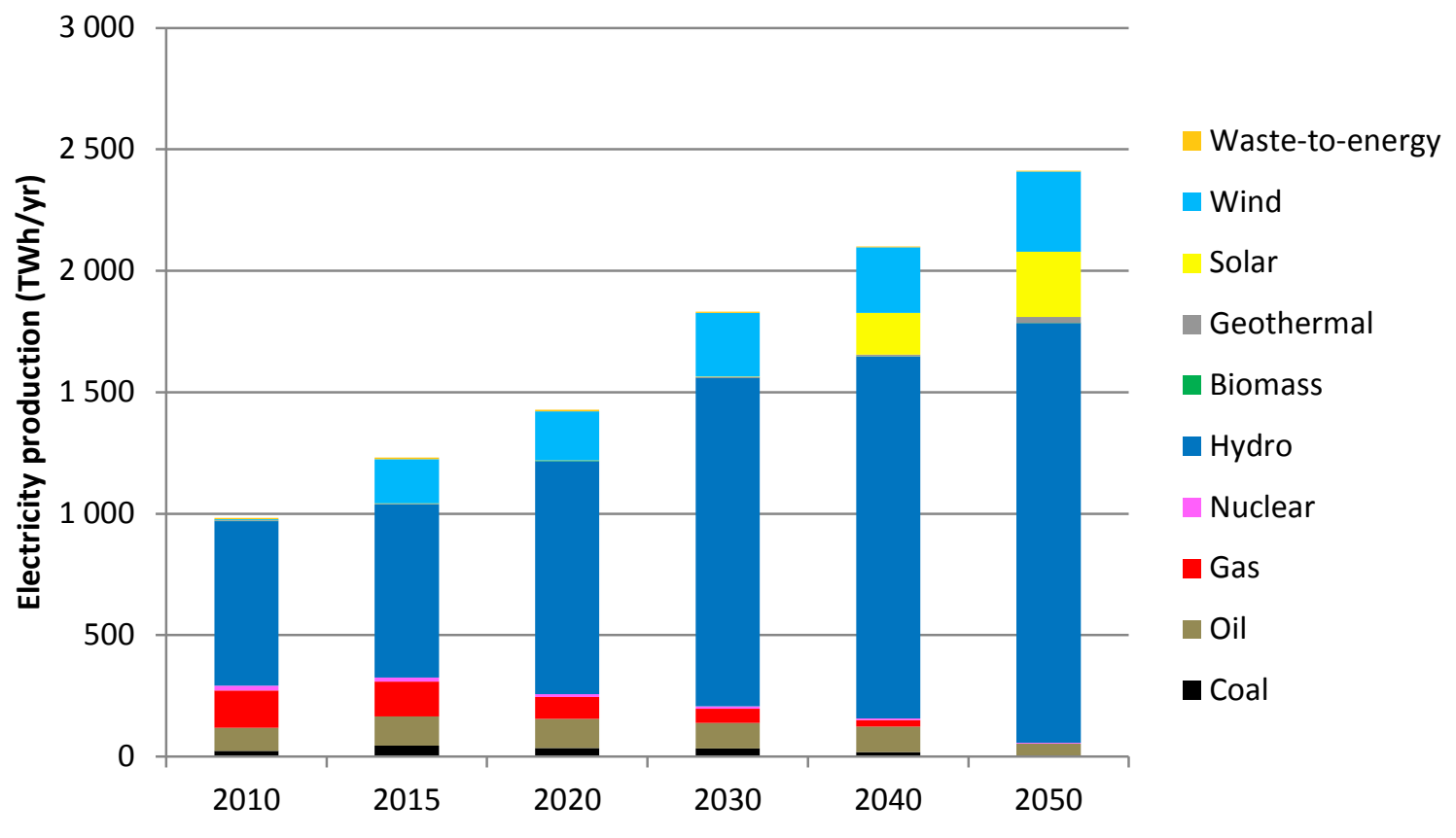

Figure 5: Electricity production in CSA-C, 2010-2050 (Business-As-Usual)

The implications of such a result are already highly interesting, and were hinted at by the Argentine and Chilean cases: with no other assumption apart from cost minimization on a long-term horizon, the model already chooses green energies as the most interesting options for electricity production. This is partly due to the fact that this scenario occurs in an ideal world where long-term centralized planning is the rule. In practice, authors such as (Arango and Larsen, 2010) have stressed the fact that market forces and national policies in e.g. Argentina may lead to a carbonization of the electricity mix in the years to come. However, these preliminary results imply that moving towards more renewable electricity in CSA-C is technically feasible and optimal from a pure costs point of view, even while social and environmental limitations and economic barriers limit its actual development.

At sub-regional level, solar energy dominates new production capacity along with hydro and wind in more than half of CSA-C by 2050 (Colombia, Peru, Ecuador, Venezuela, Argentina, Southeastern Brazil and Central America). BWC's strong solar potential, however, is not used since hydro and wind power together prove sufficient to satisfy the region's electricity needs. Southeastern Brazil satisfies part of its power supply with decentralized oil-based production; its electricity, together with that of Chile and Argentina, is the most expensive on the continent. However, Argentina resorts to solar energy and Chile to solar, wind and geothermal energy to complement their hydro production capacity; the power mix of these two regions is thus less emissive than BSE's. Interestingly, CYC does not tap into its geothermal potential, even though it possesses the biggest resource on the whole continent. This result may seem counter-intuitive, since many Central American countries have been installing pilot projects for geothermal production in the past ten years; however, it is in line with the fact that no Central American NDC mentions geothermal energy as an option for emissions mitigations, save for Grenada's and Dominica's. In fact, according to Dolezal et al. (2013), only Nicaragua considered geothermal development as a priority in its national energy plan. These authors explain this lack of interest by "high upfront costs for resource assessment and test drilling", with somewhat less expensive oil imports than Chile's.

Figure 6 displays the variations in power generation for our four climate scenarios compared to $B A U$, from the least stringent (NAMAs) to the most stringent (Cond_TALyC). The impact of climate pledges on the electricity sector is most obvious in the increase of the amount of electricity generated. While this increase is moderate in NAMAs $(+0 \%$ in 2030, $+25 \%$ in 2050 over BAU), it is overwhelming in the most stringent climate scenario, Cond_TALyC, leading to a more than doubling of regional electricity production compared with BAU towards the end of the period $(+23 \%$ in 
$2030,+93 \%$ in 2050 ). Electrification is thus used heavily by the model as a decarbonization option, the more so when pledges pressure increase.

Overall, hydropower is the main driver of this production increase. This interest towards hydropower production is not new in CSA-C and not even half the region's technical potential has been tapped today (for a review of literature see (Postic, 2015)); however, due to environmental concerns and social opposition, all of this potential may not be actually available. On this point, the contradiction existing in Brazil between official and academic sources is enlightening: as (Lucena et al., 2015) state that "the country faces the near-exhaustion of its environmentally feasible hydro potential", the State Decennial expansion plan 2022 (EPE, 2013) still considers a 29 GW expansion of hydropower capacities between 2015 and 2022 - that is, nearly 30\% additional hydropower capacity in 7 years (EPE, 2013 , p. 86). We then performed a sensitivity analysis on the available hydro potential, considering that only half of the technical remaining potential is environmentally and socially feasible. In such a case and under strong climate constraints (Cond_TALYC scenario), hydropower is replaced in the continent towards 2050 by solar electricity (240 $\mathrm{TWh} / \mathrm{yr}$ ), followed by oil (172 TWh/yr), gas (133 TWh/yr) and wind (133 TWh/yr). Geothermal and nuclear power also contribute to replace hydropower, to a lesser extent. However, the generation drop in the case of low hydro potentials and strong climate constraints in 2050 is negligible $(-1.8 \mathrm{TWh} / \mathrm{yr})$, confirming a certain robustness of our results concerning the role of electricity as a main mitigation driver for the region.

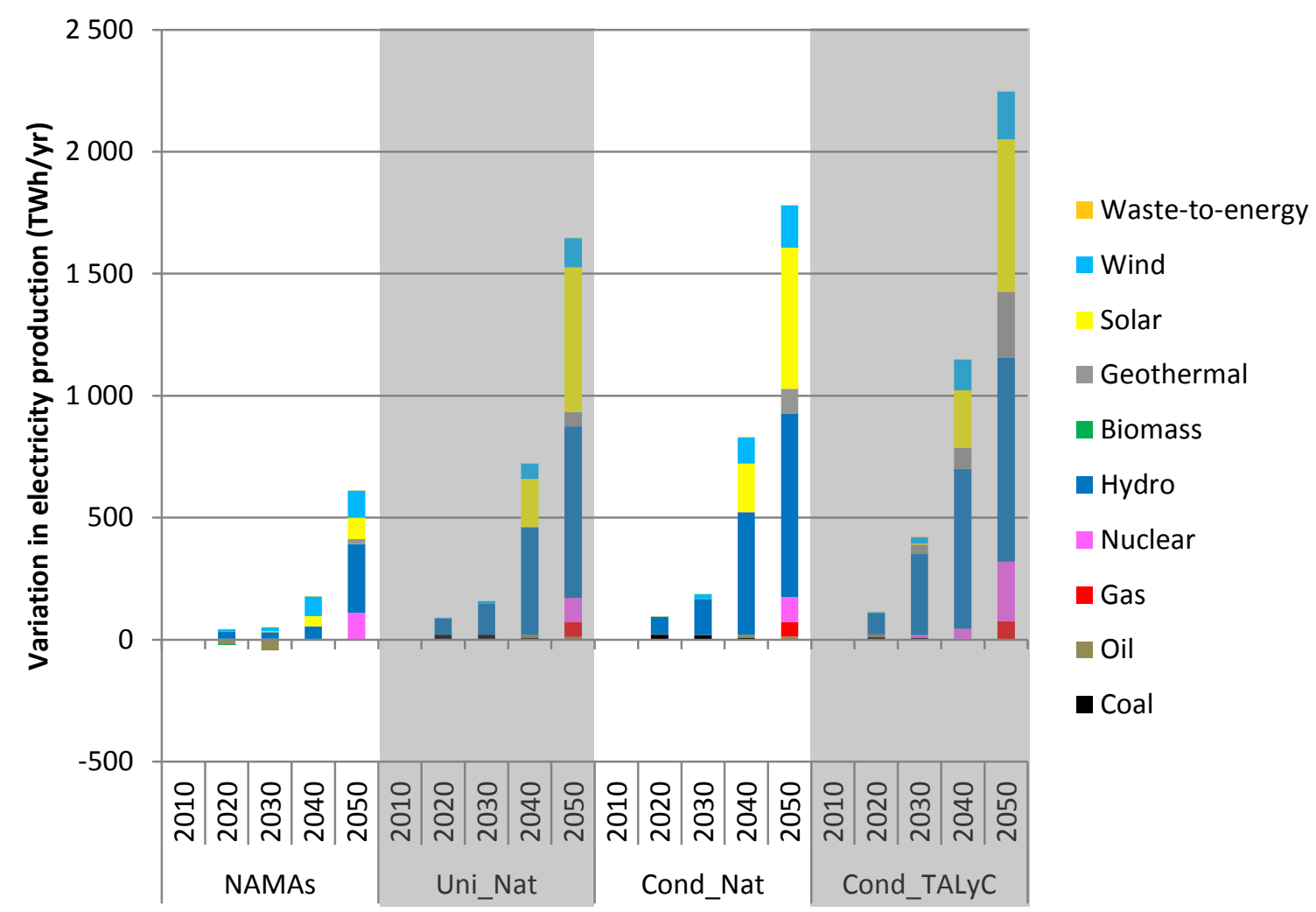

Figure 6: Modification of the power mix relative to $B A U$ in climate scenarios

This massive electrification is mainly due to Brazil, followed by Argentina and Chile. BSE presents the most drastic change from BAU to Cond_TALYC in 2050. Electricity production increases by $125 \%$ in 2050, lifted mostly by solar energy, along with the installation of new nuclear capacity. This behavior is mostly driven by a shift in industrial demand (machine drive power, process heat and steam production, in various industrial sectors) from imported LNG towards electricity. BSE's dependency on imported electricity also increases, driving BWC, BPU and ARG to increase their electricity production. Chile's industrial sector shifts to electricity as well, yet the country recurs almost exclusively to indigenous power production, increasing among others its nuclear and geothermal capacities. Chile's nuclear potential in T-ALyC is based on the World Nuclear Association forecast, yet it could be challenged in a post- 
Fukushima world as a politically unlikely option. Geothermal was indeed pointed out by various authors as an interesting option to decarbonize Chile's power mix (Carvallo et al., 2014; Lahsen et al., 2015).

The main contribution of CSA-C's electricity mix to regional emission targets is thus based on an increase of the absolute amount of electricity produced, by up to $93 \%$ in 2050. Clean electricity then competes with other forms of energy to provide end-use energy services, mainly gas in the industry sector. This electrification is strongly driven by $B S E$, whose very high electricity needs trigger exports from all of its neighbors.

While the relevance of NDCs and their impact on CSA-C's power mix is certain, the impact of NAMAs is more mixed. On the one hand, Chile and Brazil's NAMAs, based on BAU projections, incontestably bring down regional emissions compared with a BAU pathway. On the other hand, NAMAs by AND and COL have little impact on the region's energy mix, for two main reasons: first, the two regions together represent $11 \%$ of the electricity generated in CSA-C in 2010 (15\% in 2050); and second, the electricity targets registered as NAMAs for COL and AND are already mostly met under $B A U$ conditions.

\subsection{Primary energy consumption decarbonizes mainly through electrification}

\subsubsection{The relevance of oil exports}

When taking export-bound oil production into account, fossil fuels dominate primary energy production, constantly accounting for more than $75 \%$ of total production (Figure 7). In 2030, fossil fuels represent $86 \%$ of CSA-C's primary production; oil alone makes up $64 \%$ of this production with $818 \mathrm{Mtoe} / \mathrm{yr}$.

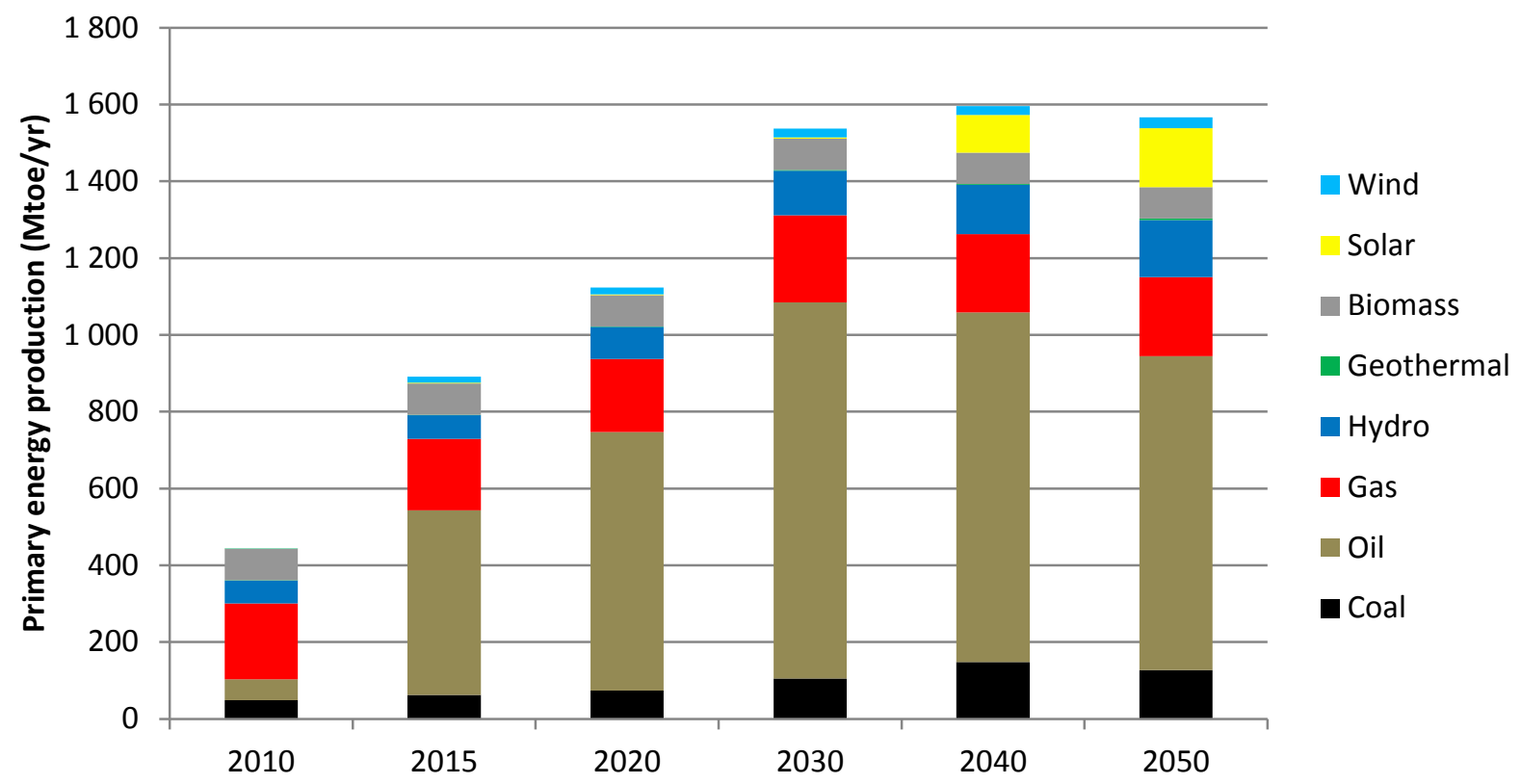

Figure 7: Primary energy production under BAU assumptions

The decrease in oil production after 2030 can be explained by two factors (see Figure 8). First, Venezuelan crude oil exports, which make up the bulk of CSA-C's exports, are capped in our model at $24 \mathrm{PJ} / \mathrm{year}$ (approx. $573 \mathrm{Mtoe} / \mathrm{yr}$ ) to avoid over-unrealistic export volumes, since global oil prices are static in this version of T-ALyC ${ }^{9}$. Due to capacity expansion inertia, this threshold is reached in 2030, marking a clear break in the upward trend. Second, after two decades of oil bounty, exporting towards its neighbors and the rest of the world, Brazil starts importing oil itself,

\footnotetext{
${ }^{9}$ Actually, this cap is already quite optimistic, due to the country's current political crisis and lack of investment capacity. However, it proves sufficiently low to avoid exhausting the country's reserves before the end of the period and allow for a realistic behavior as far as internal consumption and regional trade are concerned.
}

Page 12 
dragging Argentina and Uruguay along with it. The conjunction of those factors starts a downward trend for oil production in 2030. In the 2030-2050 period, the rise of solar energy in the primary mix offsets this trend, leading to almost stationary primary energy production between 2030 and 2050. However, primary solar energy as considered here is incoming solar radiation before conversion into electricity ${ }^{10}:$ its contribution to primary energy production is thus significantly higher than its actual output in terms of electricity/heat production.

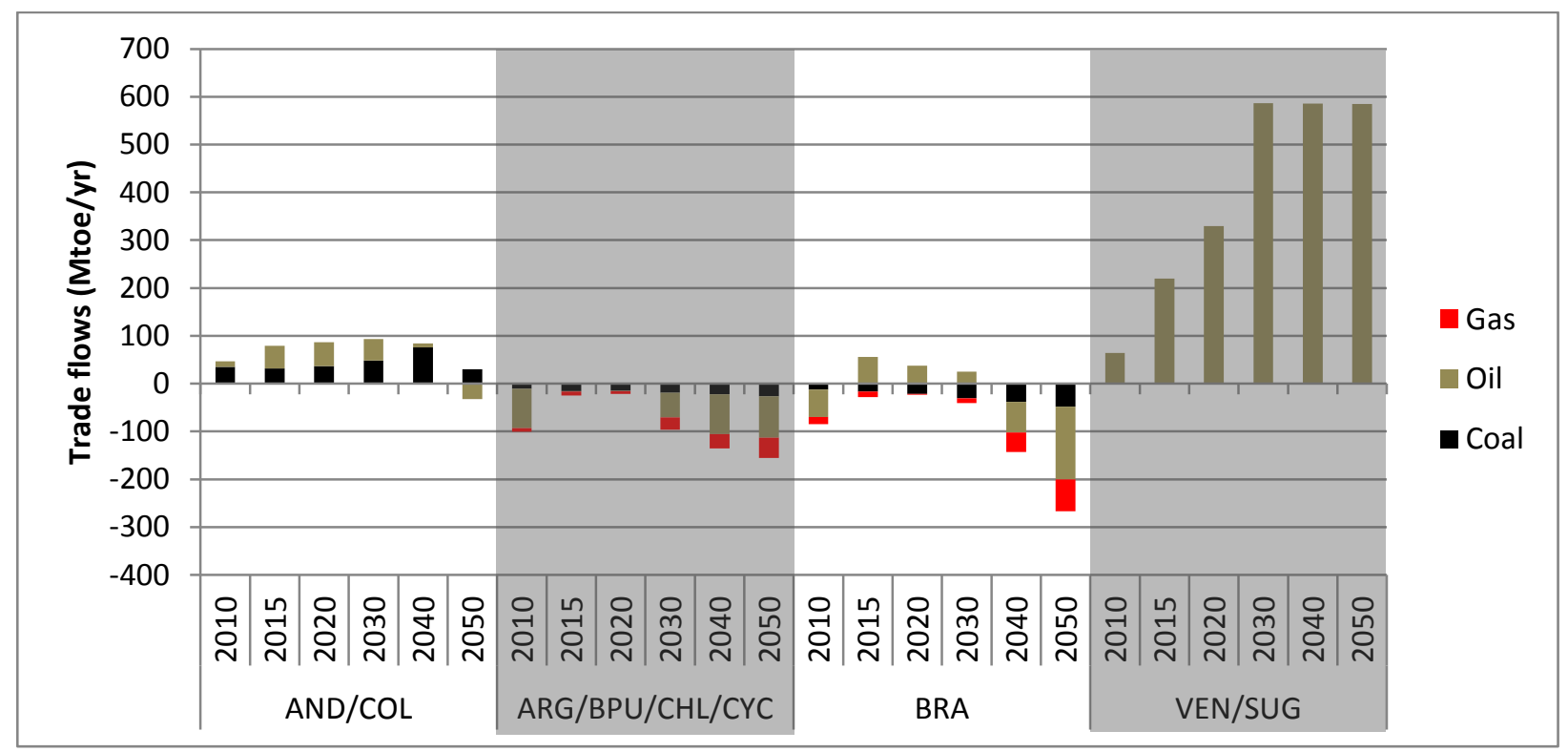

Figure 8: CSA-C's fossil fuel trade with the rest of world (BAU)

The overwhelming majority of exported oil is crude, with few associated emissions ${ }^{11}$. Nevertheless, climate pledges could still impact oil trade in CSA-C, in three main ways:

- Regardless of decisions and pledges from other world regions, penalizing the regional consumption of fossil fuels (through taxes, subsidies on green fuels, etc.) would indeed make them less competitive on the internal market, but would not impact exports' competitiveness. We can thus expect that the decrease in primary fossil energy production will at best be limited, with a shift from internal consumption to exports. Financing a green subsidy policy could even lead to an increase in oil production when the takeoff of renewables is bound to the redistribution of an oil rent, as studied by Goldemberg et al. (2014).

- Export volumes can be voluntarily reduced as part of a political volition to reduce the continent's contribution to global emissions. The Yasuni-ITT initiative, although unsuccessful, established an interesting case for this type of new cooperation framework (see e.g. Pellegrini et al., 2014; Vallejo et al., 2015).

- Export volumes can also drop as a result of international climate pledges which would reduce global oil demand and bring down oil prices. Venezuela produces heavy oil at relatively high costs (breakeven price estimated at US\$30, compared to US\$ 10 for Saudi Arabian wells) and would be among the first impacted by such a slowdown (its budget breakeven is considered by most analysts to be around US\$ 120). This assumption is confirmed by authors such as Labriet et al. (2015). In fact, this scenario is already happening in Venezuela, where the 2015 drop in oil prices worsened the existing economic crisis and triggered major street protests urging President Maduro to step down in 2016.

\footnotetext{
${ }^{10}$ That is, without the energy losses incurred by solar panels/connecting lines. More than $85 \%$ of this primary energy is actually lost in the conversion process.

${ }^{11}$ In 2014, according the US-Energy Information Administration, Venezuela produced 2.69 million barrels/day of oil and other petroleum products, yet the country's nameplate domestic refinery capacity is 1.3 million barrels/day and part of these facilities need refurbishment to operate to their maximal capacity.
} 
The risk inherent to such a scenario would be that the no-longer-exported oil could be consumed within CSA-C itself, replacing other renewable forms of energy production, starting with biofuels. As a first approximation of this issue, T-ALyC was run with oil prices 50\% lower than their current TIAM value: solar energy all but disappeared from the region's primary energy mix. Coal consumption was also reduced (-42 Mtoe/yr in 2050), yet the increase of oil and gas consumption (+310 Mtoe/yr in 2050) more than offset this slight improvement.

\subsubsection{Transport and industry drive regional energy decarbonization}

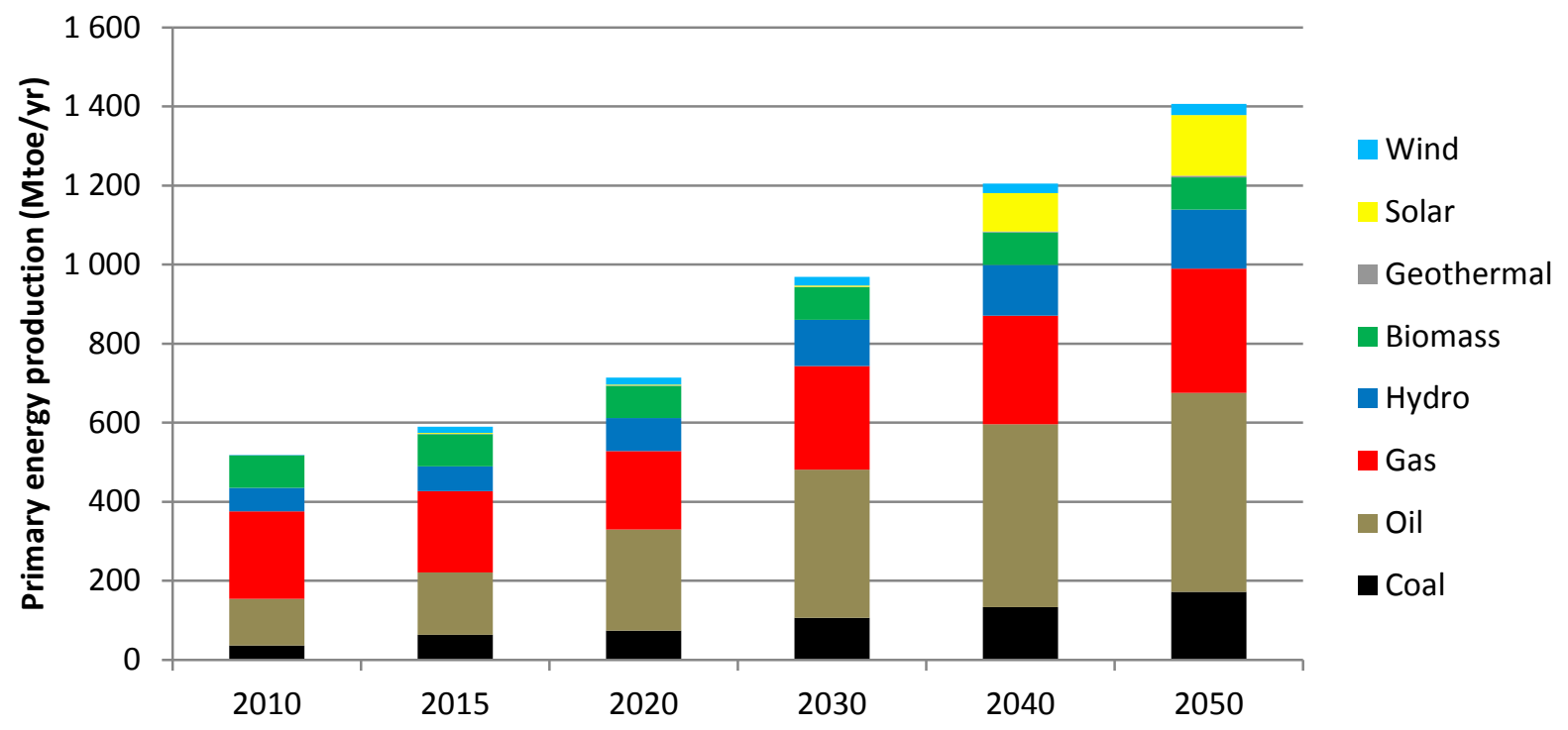

Figure 9: Primary energy consumption in BAU case, 2010-2050 - Net of trade

Figure 9 shows primary energy production in CSA-C minus net energy trade, that is, the actual regional primary energy supply. This supply increases by $172 \%$ between 2010 and 2050 . The share of oil is considerably reduced compared to Figure 7 and, conversely, the share of gas increases, mainly due to net gas imports in Brazil and Chile. The overall fossil fuel share remains above $70 \%$ of total primary consumption during the whole period; CSA-C's primary energy mix is thus quite heavily fossil-fuel based, despite clean electricity generation and even without accounting for oil exports. Oil, natural gas and coal all increase their absolute contribution to CSA-C's total primary energy supply between 2010 and 2050; despite promising potential and encouraging prospects ${ }^{12}$, biomass energy does not increase its participation to CSA-C's energy mix in the absence of climate constraints.

As shown on Figure 10, the power sector is the first consumer in 2010; however, its dependence on fossil fuels decreases with time as renewable production increases and fossil production efficiency improves. On the other hand, fossil fuel consumption increases dramatically in the industry and transport sectors, reflecting the strong regional economic growth: $+178 \%$ for transport between 2010 and $2050,+252 \%$ for industry. Quite logically, while industrial demand is met by all three fossil fuels (oil, coal and natural gas), the transport sector relies mostly on oilbased fuels, despite an interesting incursion into natural gas in the last decade.

\footnotetext{
${ }^{12}$ Among them, the works of Margulis et al. (2011) and Moreira et al. (2014) are quite optimistic about biomass options for Brazil's energy future. More information on the modeling of biomass in T-ALyC is available in (Postic, 2015).
} 


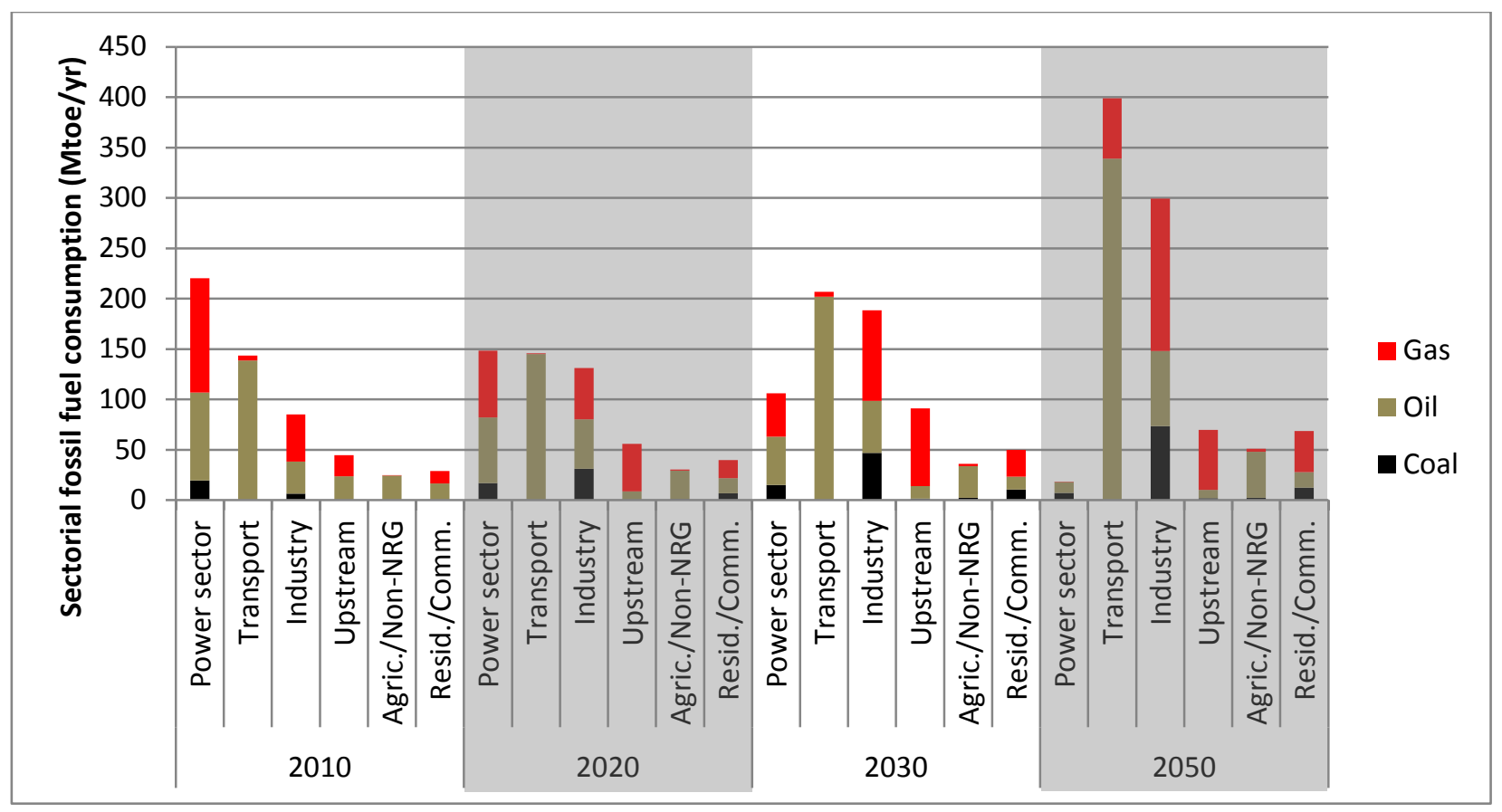

Figure 10: Fossil fuel consumption in 2010, 2030 and 2050 (BAU)

Brazil is still the continent's main energy consumer in 2050 with 503 Mtoe/yr, far ahead of its three main followers (Venezuela, Argentina and Colombia consume 247.5, 152.4 and 135/7 Mtoe/yr respectively). Coal is used in nearly all T-ALyC regions to different degrees, yet only Colombia is a relevant producer, exporting towards Venezuela, the Andean States, Northern Brazil and outside the region. Southeastern Brazil also produces some lower-quality coal; however, most of its consumption is satisfied by coal imports from international markets. Brazilian coal is mainly consumed by non-energy petrochemical feedstocks, industrial heat and steam. Natural gas is present in all model regions in 2030 and 2050 yet only AND, BPU and VEN meet their energy needs without external imports throughout the period. By 2050, CHL, BSE, and CYC rely almost entirely on imports (mostly LNG) for their domestic gas consumption; BWC imports half of its consumption from BPU, and even Argentina complements its domestic production through LNG imports, despite large shale gas reserves. Argentine gas is used mainly for industrial applications, followed by residential uses. Venezuela increases its use of natural gas, mainly to fuel its upstream sector (followed, fairly closely, by industry); this is mostly owed to a better use of the country's flared and vented gas. The country's oil is mainly directed to exports. The rest of the continent, including Brazil, consumes most of its gas for industrial purposes, the second use being transport.

Apart from petrochemical feedstocks, coal and gas can be substituted by renewable energy carriers for their main uses (industrial heat and steam, residential heat). Transport uses, both for oil and gas, are less substitutable, since only biofuels could be expected to fill the gap in the short term. Dedicated energy crops are already used to their full potential in Brazil and Argentina in our BAU scenario, for ethanol (Brazilian sugarcane) and biodiesel (Argentine soy) production; however, other solid biomass sources are used little under business-as-usual conditions. Chile and Central America also tap into their energy crop production potential, yet the resource is directed more towards industrial and residential uses.

Figure 11 displays the variations in primary energy supply for the four climate scenarios compared to BAU, from the least stringent (NAMAs) to the most stringent (Cond_TALyC). The decline in fossil fuels in primary energy production, due to the rise of electricity as a privileged clean energy carrier, appears clearly from 2030 onwards. 


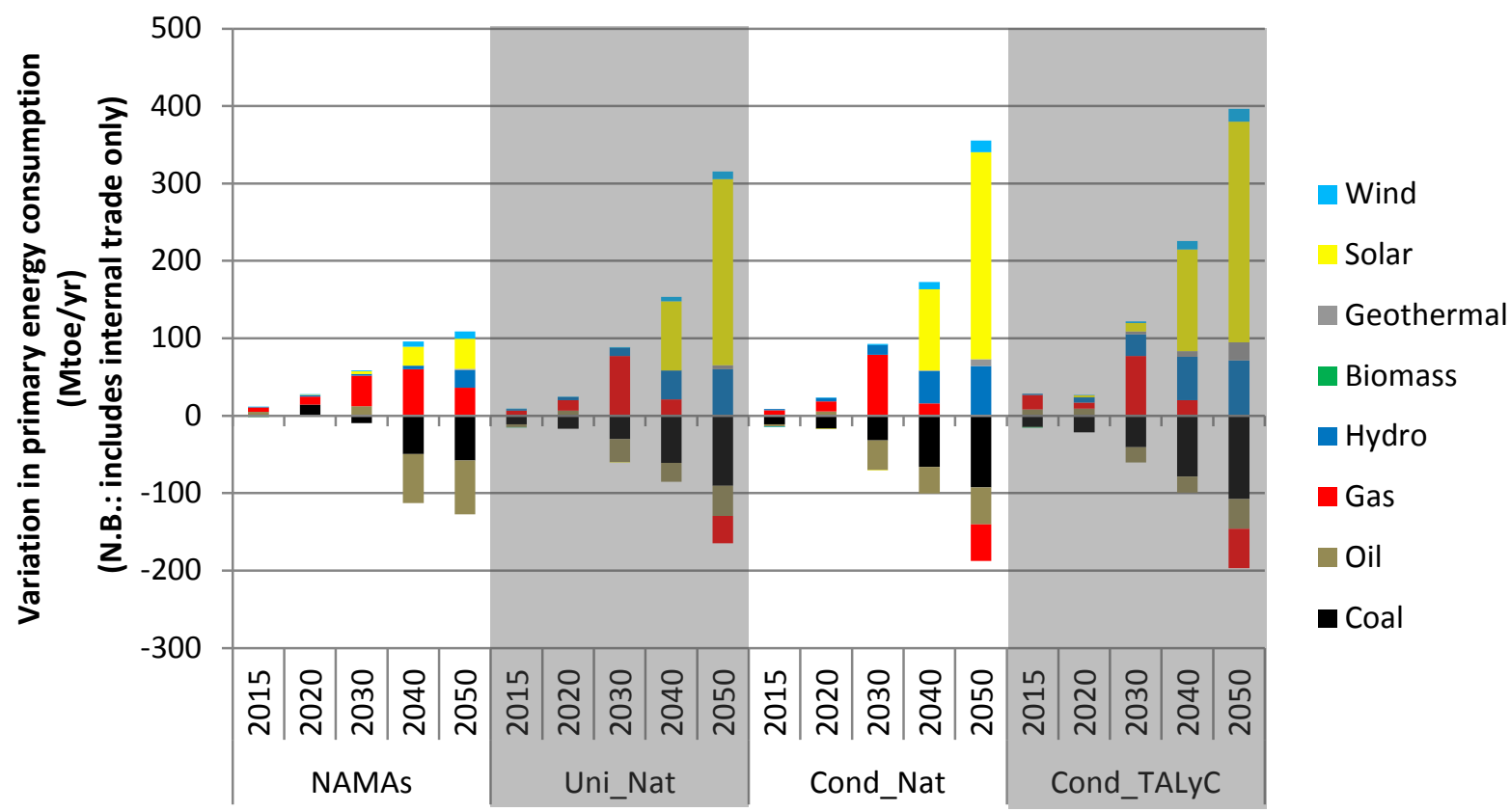

Figure 11: Modification of primary energy consumption relative to $B A U$ in climate scenarios

As shown on Figure 12, electrification is preferred to energy efficiency across all economy sectors save transport: the amount of energy consumed by each sector does not vary much between BAU and Cond_TALyC while its composition evolves a lot. Residential energy consumption is even seen to increase, but this is a reporting artifact: this increase is due to decentralized rooftop solar heating, which displaces gas for residential applications. As solar resource use is reported in primary energy units, its contribution is over-emphasized.

Ultimately, the two main sectors for energy decarbonization are industry and transport, through electrification and energy efficiency measures. Residential energy consumption is also strongly decarbonized, through electrification and decentralized solar heat generation; however, this sector's share of overall energy consumption is small, leading to a diminutive sectorial contribution to emissions reductions. In particular, T-ALyC's results for Argentina are similar to those of Tanides et al. (2006): despite a strong effort of the residential and commercial sectors (these sectors use $90 \%$ and $65 \%$ of electricity and renewables in 2050 respectively in the Cond_TALYC scenario, against $20 \%$ and $50 \%$ in $B A U)$, the absolute mitigation provided by Argentine industry is still larger. 


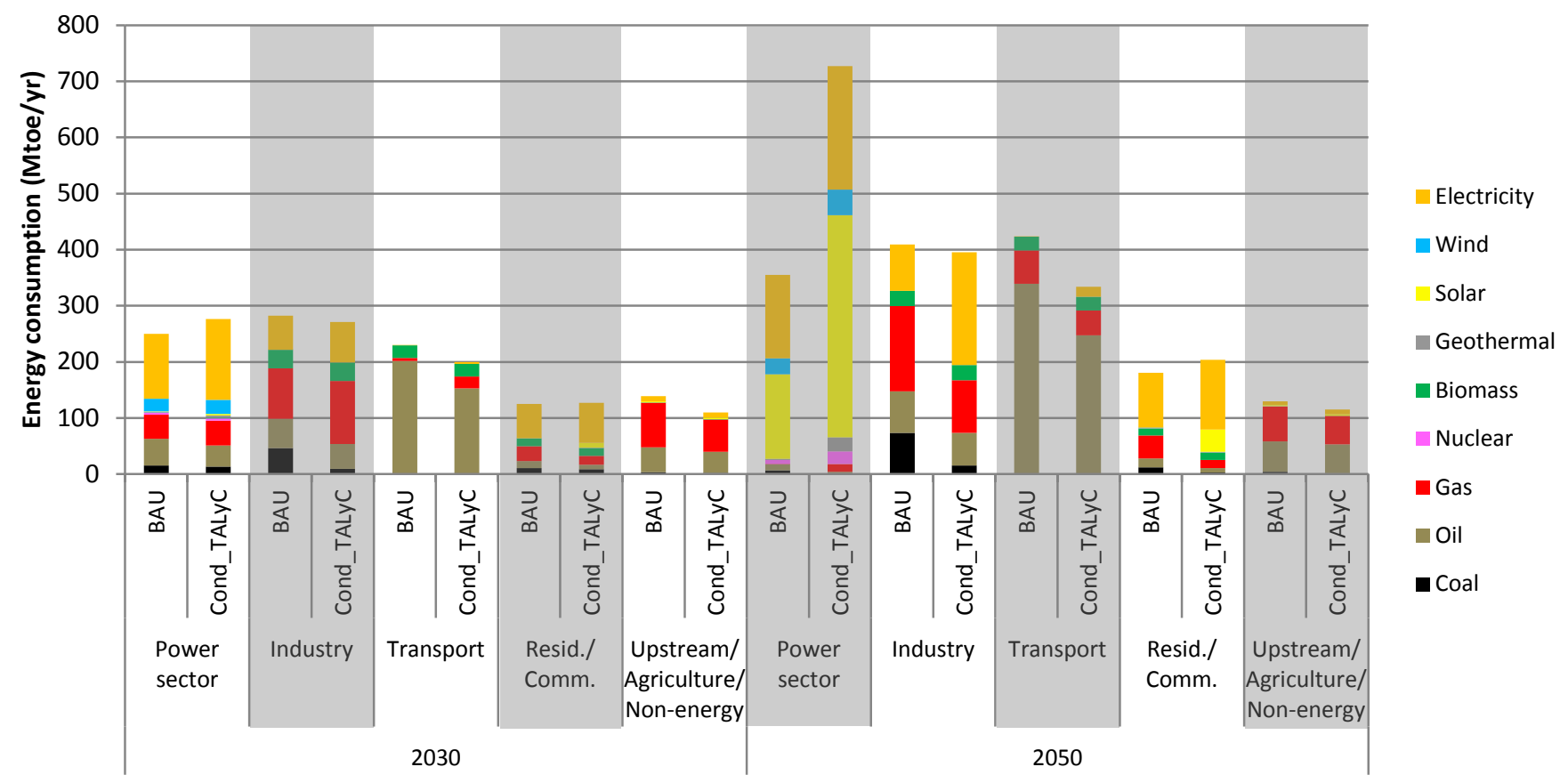

Figure 12: End-use energy consumption according to consumptions sectors, in BAU and Cond_TALyC scenarios

\subsection{Non-energy emissions and end-use efficiency measures}

\subsubsection{Non-energy emissions}

Although less emissive than global averages, we have shown that CSA-C's energy production offers valuable emission mitigation options, mainly through further electrification of the energy system. However, the energy sector does not hold the highest emissions reduction potential in CSA-C, given the weight of forestry and agriculture in the continent's emissions (cf. Figure 3, p.8). In this last paragraph, we review various non-energy mitigation options and their contribution to GHG emissions reduction to contextualize the energy sector's contribution to fulfilling regional climate commitments. Figure 13 shows GHG emissions, sector by sector, under the BAU, NAMAs and Cond_TALyC pledge scenarios, for the whole region. Figure 14 details GHG abatement in the Cond_TALyC scenario.

AFOLU is CSA-C's most emitting sector, totaling $46 \%$ of regional emissions in 2030 in the $B A U$ scenario $\left(2.2 \mathrm{GtCO}_{2} \mathrm{eq}\right.$ out of $4.8 \mathrm{GtCO}_{2}$ eq total emissions). The industry and transport sectors together account for $28 \%$ of $\mathrm{GHG}$ emissions; the energy sector (oil refining and electricity production) comes third with $21 \%$ of total emissions. The share of transport and industry increases to $41 \%$ in 2050 , yet AFOLU still represents $42 \%$ of the continent's emissions. This sector also accounts for 58\% of total GHG abatement in 2030 and $46 \%$ in 2050 under the Cond_TALyC scenario. It is worth noting that due to the virtuous trend highlighted in paragraph 3.2 for electricity, energy emissions already decrease in Business-as-Usual conditions, and energy is the only sector showing this downward trend. 


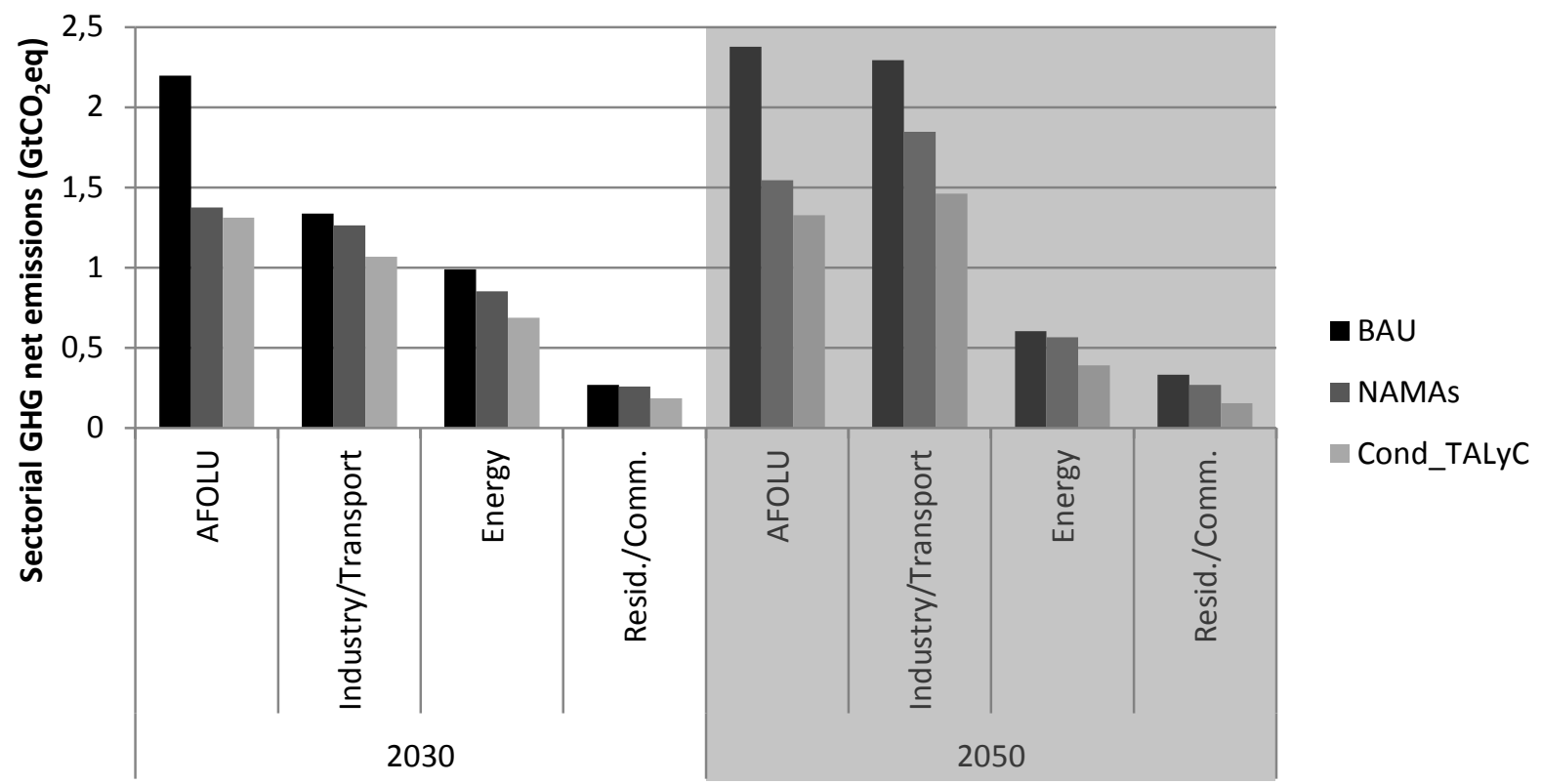

Figure 13: GHG net emissions by sector, under BAU, NAMAs and Cond_TALyC scenarios

Figure 14 focuses specifically on emissions absorption. The gray shading concerns absorption in the energy sector, green shows forestry options and red indicates GHG abatement options deployed in end-use sectors. AFOLU appears clearly as the main contributor to $\mathrm{GHG}$ emissions abatement by a huge margin, with $872 \mathrm{MtCO}_{2} \mathrm{eq}$ emissions avoided by combating deforestation and promoting reforestation (in 2030, in Cond_TALYC). Carbon storage, although less visible than AFOLU, provides also a valuable contribution to emissions mitigation: together, enhanced Oil \& Gas Recovery and Storage in depleted fields account in Cond_TALyC for $40 \mathrm{MtCO}_{2}$ eq of emission reductions, i.e. around $12 \%$ of all energy-related emission reductions in 2030 . Proper handling of flared gases cuts another $17 \mathrm{MtCO}_{2}$ eq (5\%) energy emissions; the remaining 83\% of energy-related reductions are due to the rise of carbon-free energies such as wind, solar and hydropower.

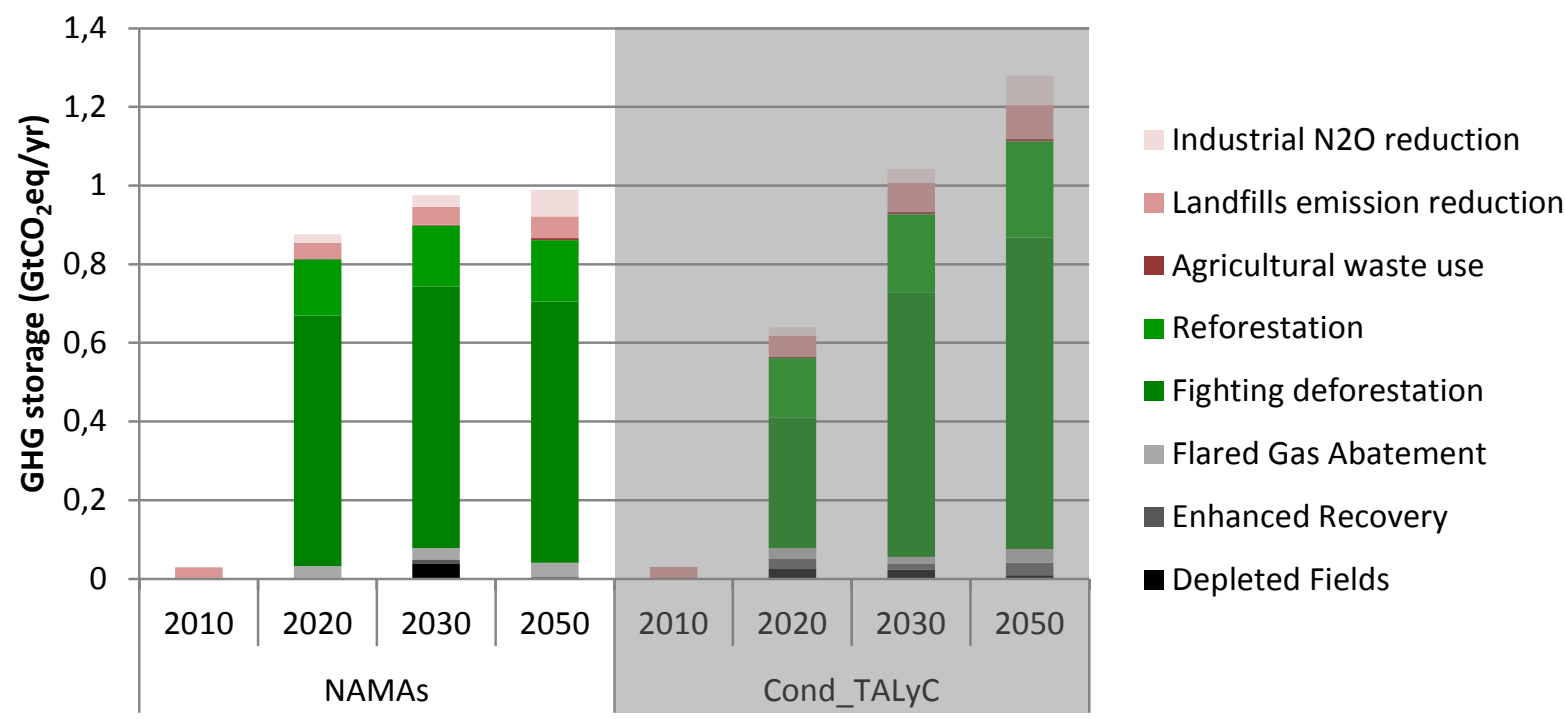

Figure 14: GHG capture and storage by sector (NAMAs and Cond_TALyC scenarios)

\subsubsection{Energy efficiency measures}

GHG mitigation in end-use sectors as displayed above only relates to specific abatement technologies, i.e. it does not consider emission reductions through e.g. fuel shift, demand reduction or efficiency improvements. However, demand-side energy efficiency measures also appear as an excellent candidate for GHG mitigation in CSA-C, as 
mentioned in section 2.2. ${ }^{13}$ Given the wide portfolio of demand-side efficiency measures and the lack of a precise cost-benefit assessment for CSA-C countries in literature, we were not able to study properly the competition between these options and supply-side efficiency, let alone forestry-based mitigation. Instead, low-growth scenarios were simulated, in which future growth for the region is assumed to be $2 \%$ lower than under Business-as-usual conditions. Given the strong link between GDP and energy demands in our model, this amounts to strong, efficient and long-lasting energy efficiency measures. We show that such a drop in end-use demand induces significant emission reductions in the absence of other climate constraints (-21\% GHG emissions compared to the original BAU scenario). However, the gap closes when applying climate constraints: a Cond_TALyC scenario with reduced demands stands 'only' $47 \%$ below the original BAU, while the normal-growth Cond_TALYC already leads to $41 \%$ emission reductions. Quite logically, end-use energy efficiency measures thus lose ground as a mitigation option as CSA-C's energy mix gets cleaner.

\subsubsection{Region-specific emission patterns, region-specific mitigation options}

The emission reduction patterns considered here are radically different from the situation in Europe, where energy is foreseen as the main contributor to emissions reduction by 2050 (European Commission, 2011). In CSA-C, due to the weight of AFOLU emissions, decarbonizing energy production and consumption is no longer the least expensive or most efficient tool to reduce GHG emissions. In fact, it would fall short of delivering more than $50 \%$ emission reduction, even at a prohibitive cost. GHG emission reductions in CSA-C should therefore be considered from a very different viewpoint: energy is not the easiest way to achieve emissions reduction because it is not the main problem; forestry, on the other hand, remains a long-run carbon sink whose management options are the focus of active research, in terms of both technology and policy aspects (Arima et al., 2014; Asner et al., 2014). In the whole world, it is estimated that deforestation and forest degradation account for $17 \%$ of GHG emissions (IPCC, 2007) and these activities are already seen as a 'low-hanging fruit' in the fight against climate change (Stern, 2007), (Buizer et al., 2014). The present work tends to confirm this trend in the case of CSA-C.

\section{Conclusions and policy implications}

This paper analyzed the energy sector's contribution to GHG emissions reduction in a post-COP21 world. We outlined the potential for GHG abatement in the energy sector of Central and South America and the Caribbean (CSA-C), and the evolutions required to realize this potential.

We investigated this issue by means of a bottom-up, long-term optimization model, based on the TIMES paradigm yet specifically designed for CSA-C: the TIMES-América Latina y el Caribe model, or T-ALyC. We compared five scenarios based on national communications to the UNFCCC: a Business-As-Usual case, a NAMAs scenario accounting for regional Nationally Adapted Mitigation Actions, a Uni_Nat scenario considering unilateral Nationally Determined Contributions to the UNFCCC, and two scenarios representing the pledges made by CSA-C's countries in the event of increased international collaboration.

In our projections, AFOLU provides $46 \%$ of regional emission reductions in 2050 in the most stringent (Cond_TALyC) scenario (Figure 13). We find that energy is not the main contributor to emission reductions in CSA-C for two main reasons: first, in our baseline, long-term economic optimization already leads to a decarbonization of the electricity sector. Further decarbonization can however be achieved by shifting to electricity in industry, as detailed on Figure 6

\footnotetext{
${ }^{13}$ A literature review of these options is available in (Postic, 2015 Chapter 5, paragraph A.5). Let us mention here that industry appears as the most promising sector for energy efficiency measures in CSA-C. According to (Borba et al., 2012), it could provide up to $55 \%$ of the country's energy-related emission reductions. Chile, Colombia, Uruguay and Argentina also mention explicitly energy efficiency as a main tool for mitigating industrial emissions.
} 
and paragraph 3.3.2: electricity production nearly doubles under stringent climate constraints. Second, the weight of deforestation and land degradation in the continent's GHG balance is considerable, and it is more economically viable to curb this trend than to decarbonize the energy mix. As a consequence, the impact of national pledges on the energy sector is real, yet feedback in terms of GHG abatement remains limited. We find that NAMAs have a fairly good impact in terms of annual GHG emissions in 2030, yet the post-2030 upward trend for GHG emissions is barely curbed compared with business-as-usual conditions. NDCs add an important contribution, further reducing absolute emissions in 2050 and slowing emissions increase towards the end of the period. The impact of climate pledges on Brazil's power system is important both in quantitative and qualitative terms: the country's electricity output more than doubles in 2050 between the business-as-usual case and the most stringent climate scenario (from $1100 \mathrm{TWh} / \mathrm{yr}$ to $2480 \mathrm{TWh} / \mathrm{yr}$ ) and solar energy takes a major share of this new electricity mix, accounting for $25 \%$ of the electricity produced in 2050 in the country. Given the weight of Brazil in the region, the consecutive impact on regional electricity is far from negligible. We also showed that a sustained drop in international oil prices could negatively impact the continent's emissions, as oil exports would be redirected towards internal consumption and displace renewable energy sources. It is worth noting that such a drop is happening today and has dramatic consequences on the Venezuelan economy, which relies quite heavily on oil exports.

The policy implications of these results are many; we summarize four of them here. First, our results confirm the initial statement that CSA-C's climate-energy issues merit ad hoc modeling at a regional scale, since CSA-C's countries share features that are quite different from the rest of the world, i.e. a highly renewable energy mix, very high renewable energy potentials along with high deforestation and degradation rates, which call for regional answers to regional issues. Second, in light of our results, clean electricity generation appears to be an economically viable option for CSA-C. It is beyond the range of this study to take non-optimality factors into account to determine a second-best optimum; however, these first results suggest that heavy subsidies on fossil fuels such as those that exist in Venezuela, Argentina and Peru, may not move in the direction of economic optimality, in addition to their environmental inefficiency. Third, the significance of Brazil in the regional fight against climate change is incontestable, since its decisions drive relevant changes in the whole regional energy mix. Last, and most important, we confirm that, in contrast to Annex I countries, energy cannot be the main focus of efforts to fight global warming in CSA-C because it is not the continent's main problem. In this region, deforestation and land degradation are not only part of the climate issue: they make up the bulk of it.

The importance of deforestation also points to one limitation of our study: although we considered energy production and transformation in a very detailed way, our representation is more limited when it comes to AFOLU, due to the weak link between energy and e.g. reforestation. Further investigation of energy and AFOLU interactions in a climate context would require internalizing a bottom-up approach of the forestry sector, building on work such as e.g. (Overmars et al., 2014). Following another research line, integrating our results back into the global TIAM energy model would extend the intuitions we developed here on the role of oil in an interesting way, providing dynamic oil price feedbacks rather than a mere sensitivity analysis. Last, one major issue related to climate change that has not been touched on here is the adaptation issue: beyond mitigation, how to prepare a strongly renewable, climate-sensitive energy mix to tackle uncertain climate change effects? This issue is currently being worked on, and partial results were published in the World Energy Outlook 2016 by the International Energy Agency.

\section{Acknowledgements}

This research paper is mostly extracted from a PhD thesis conducted at MINES ParisTech (Postic, 2015) and supported by the Chair Modeling for Sustainable Development, driven by MINES ParisTech, Ecole des Ponts ParisTech and AgroParisTech, and supported by ADEME, EDF, SCHNEIDER ELECTRIC and GRTgaz. The funding body 
was not involved in study design; collection, analysis and interpretation of data; the writing of the report; or the decision to publish.

\section{Bibliography}

Akimoto, K., Sano, F., Homma, T., Oda, J., Nagashima, M., Kii, M., 2010. Estimates of GHG emission reduction potential by country, sector, and cost. Energy Policy, Large-scale wind power in electricity markets with Regular Papers 38, 3384-3393. doi:10.1016/j.enpol.2010.02.012

ALACERO, 2013. América Latina en cifras - Asociación Latinoamericana del Acero. Asociación Latinoamericana del Acero.

Arango, S., Larsen, E.R., 2010. The environmental paradox in generation: How South America is gradually becoming more dependent on thermal generation. Renew. Sustain. Energy Rev. 14, 2956-2965. doi:10.1016/j.rser.2010.07.049

Arima, E.Y., Barreto, P., Araújo, E., Soares-Filho, B., 2014. Public policies can reduce tropical deforestation: Lessons and challenges from Brazil. Land Use Policy 41, 465-473. doi:10.1016/j.landusepol.2014.06.026

Asner, G.P., Knapp, D.E., Martin, R.E., Tupayachi, R., Anderson, C.B., Mascaro, J., Sinca, F., Chadwick, K.D., Higgins, M., Farfan, W., Llactayo, W., Silman, M.R., 2014. Targeted carbon conservation at national scales with highresolution monitoring. Proc. Natl. Acad. Sci. doi:10.1073/pnas.1419550111

Bassi, A.M., Baer, A.E., 2009. Quantifying cross-sectoral impacts of investments in climate change mitigation in Ecuador. Energy Sustain. Dev. 13, 116-123. doi:10.1016/j.esd.2009.05.003

Borba, B.S.M.C., Lucena, A.F.P., Rathmann, R., Costa, I.V.L., Nogueira, L.P.P., Rochedo, P.R.R., Castelo Branco, D.A., Júnior, M.F.H., Szklo, A., Schaeffer, R., 2012. Energy-related climate change mitigation in Brazil: Potential, abatement costs and associated policies. Energy Policy, Special Section: Fuel Poverty Comes of Age: Commemorating 21 Years of Research and Policy 49, 430-441. doi:10.1016/j.enpol.2012.06.040

Buizer, M., Humphreys, D., de Jong, W., 2014. Climate change and deforestation: The evolution of an intersecting policy domain. Environ. Sci. Policy, Climate change and deforestation: the evolution of an intersecting policy domain 35, 1-11. doi:10.1016/j.envsci.2013.06.001

Carvallo, J.P., Hidalgo-Gonzalez, P., Kammen, D.M., 2014. Envisioning a sustainable Chile.

CIER, 2013. Síntesis Informativa energética de los países de la CIER, datos 2012.

CIER, 2011. Síntesis informativa energética de los países de la CIER, datos 2009.

Colgan, J.D., 2014. Oil, Domestic Politics, and International Conflict. Energy Res. Soc. Sci. 1, 198-205. doi:10.1016/j.erss.2014.03.005

Di Sbroiavacca, N., Nadal, G., Lallana, F., Falzon, J., Calvin, K., 2016. Emissions reduction scenarios in the Argentinean Energy Sector. Energy Econ. 56, 552-563. doi:10.1016/j.eneco.2015.03.021

Di Sbroiavacca, N., Nadal, G., Lallana, F., Falzon, J., Calvin, K., 2015. Emissions reduction scenarios in the Argentinean Energy Sector. Energy Econ. doi:10.1016/j.eneco.2015.03.021

Dolezal, A., Majano, A.M., Ochs, A., Palencia, R., 2013. The Way Forward for Renewable Energy in Central America.

ECLAC, 2014. The economics of climate change in Latin America and the Caribbean: Paradoxes and challenges. ECLAC.

Elberg Nielsen, A.S., Plantinga, A.J., Alig, R.J., 2014. Mitigating climate change through afforestation: New cost estimates for the United States. Resour. Energy Econ. 36, 83-98. doi:10.1016/j.reseneeco.2013.11.001

EPE, 2013. Plano Decenal de Expansao de Energia 2022. Empresa de pesquisa energética.

European Commission, 2014. Sixth national Communication from the European Union under the UNFCCC.

European Commission, 2011. Roadmap for moving to a low-carbon economy in 2050.

Fundación Bariloche, 2008. Argentina: Diagnóstico, prospectivas y lineamiento para definir estrategias posibles ante el Cambio Climático.

Garcés, P., Garcia, F., Parra, C., Preciado, V., Lim, S.H., Franco, E., 2012. Potencial de Recursos Energéticos y Minerales en América del Sur: Coincidencias Jurídicas hacia una Estrategia Regional.

Global Energy Observatory, 2013. Information on Global Energy Systems and Infrastructure [WWW Document]. globalenergyobservatory.org. URL http://globalenergyobservatory.org/ (accessed 8.4.14). 
Goldemberg, J., Schaeffer, R., Szklo, A., Lucchesi, R., 2014. Oil and natural gas prospects in South America: Can the petroleum industry pave the way for renewables in Brazil? Energy Policy 64, 58-70. doi:10.1016/j.enpol.2013.05.064

Gonzalez Arenas, J.J., Etter Rothlisberger, A.A., Sarmiento López, A.H., Orrego Suaza, S.A., 2011. Análisis de tendencias y patrones espaciales de deforestación en Colombia. Instituto de Hidrología, Meteorología y Estudios Ambientales de Colombia.

Hof, A.F., den Elzen, M.G.J., Roelfsema, M., 2013. The effect of updated pledges and business-as-usual projections, and new agreed rules on expected global greenhouse gas emissions in 2020. Environ. Sci. Policy 33, 308319. doi:10.1016/j.envsci.2013.06.007

Hoornweg, D., Bhada-Tata, P., 2012. What a Waste - A Global Review of Solid Waste Management. The World Bank. IEA, 2014. World Energy Statistics - 2013.

IER, 2006. Review of resources and trade of fossil energy resources in the TIAM model.

IMF, 2014. International Monetary Fund - World Economic Outlook Database [WWW Document]. URL http://www.imf.org/external/pubs/ft/weo/data/changes.htm (accessed 6.17.14).

IPCC, 2014. Summary for Policymakers, in: Climate Change 2014: Impacts, Adaptation, and Vulnerability. Part A: Global and Sectoral Aspects. Contribution of Working Group II to the Fifth Assessment Report of the Intergovernemental Panel on Climate Change. Cambridge University Press, Cambridge, United Kingdom and New York, NY, USA.

IPCC, 2007. Climate Change 2007: Synthesis Report. Contribution of Working Groups I, II and III to the Fourth Assessment Report of the Intergovernmental Panel on Climate Change. Geneva, Switzerland.

Labriet, M., Drouet, L., Vielle, M., Loulou, R., Kanudia, A., Haurie, A., 2015. Assessment of the Effectiveness of Global Climate Policies Using Coupled Bottom-up and Top-down Models, Climate Change and Sustainable Development. Fondazione Eni Enrico Mattei, Milano.

Lahsen, A., Rojas, J., Morata, D., Aravena, D., 2015. Geothermal Exploration in Chile: Country Update, in: Proceedings World Geothermal Congress 2015. pp. 19-24.

Loulou, R., Labriet, M., 2008. ETSAP-TIAM: the TIMES integrated assessment model Part I: Model structure. Comput. Manag. Sci. 5, 7-40. doi:10.1007/s10287-007-0046-z

Loulou, R., Remme, U., Kanudia, A., Lehtila, A., Goldstein, G., 2005. Documentation for the TIMES model: Part I. Energy Technol. Syst. Anal. Programme Available Httpwww Etsap Orgdocumentation Asp.

Lucena, A.F.P., Clarke, L., Schaeffer, R., Szklo, A., Rochedo, P.R.R., Nogueira, L.P.P., Daenzer, K., Gurgel, A., Kitous, A., Kober, T., 2015. Climate policy scenarios in Brazil: A multi-model comparison for energy. Energy Econ. doi:10.1016/j.eneco.2015.02.005

MAE, 2011. Segunda Comunicación Nacional sobre Cambio Climático. Ministerio del Ambiente del Ecuador, Quito.

Margulis, S., Dubeux, C.B.S., Marcovitch, J., 2011. The Economics of Climate Change in Brazil: Costs and Opportunities. São Paulo.

Matthews, H.D., Graham, T.L., Keverian, S., Lamontagne, C., Seto, D., Smith, T.J., 2014. National contributions to observed global warming. Environ. Res. Lett. 9, 14010. doi:10.1088/1748-9326/9/1/014010

MCT, 2010. Second national communication of Brazil to the United Nations Framework convention on Climate Change. Minister of Science and Technology - Federative Republic of Brazil, Brasilia.

MCTI, 2016. Third National Communication of Brazil to the United Nations Framework Convention on Climate Change. Minister of Science, Technology and Innovation - Federative Republic of Brazil, Brasilia.

MINAM, 2010. El Perú y el Cambio Climático. Ministerio del Ambiente del Perú, Lima.

Ministerio de Ambiente de Colombia, 2012. Plan Nacional de Restauración.

Ministerio del Ambiente del Ecuador, 2012. Línea Base de Deforestación del Ecuador Continental. Quito.

MMA, 2011. Segunda comunicación nacional de Chile ante la convención marco de las Naciones Unidas sobre cambio climático, Ministerio del Medio Ambiente-Gobierno de Chile. ed. Maval Chile, Santiago, Chile.

MMAyA, 2009. Segunda Comunicacion del estado plurinacional de Bolivia ante la Convención Marco de las Naciones Unidas sobre el Cambio Climático. Ministerio de Medio Ambiente y Agua - Estado Plurinacional de Bolivia, La Paz.

Moreira, J.R., Pacca, S.A., Parente, V., 2014. The future of oil and bioethanol in Brazil. Energy Policy 65, 7-15. doi:10.1016/j.enpol.2013.09.055

MVOTMA, 2010. Tercera Comunicación Nacional del Uruguay a la Conferencia de la Partes en la Convención Marco de la Naciones Unidas sobre el Cambio Climático. Ministerio de Vivienda, Ordenamiento Territorial y Medio Ambiente - Gobierno de Uruguay, Montevideo. 
Nepstad, D., Soares-Filho, B.S., Merry, F., Lima, A., Moutinho, P., Carter, J., Bowman, M., Cattaneo, A., Rodrigues, H., Schwartzman, S., McGrath, D.G., Stickler, C.M., Lubowski, R., Piris-Cabezas, P., Rivero, S., Alencar, A., Almeida, O., Stella, O., 2009. The End of Deforestation in the Brazilian Amazon. Science 326, 1350-1351. doi:10.1126/science.1182108

Overmars, K.P., Stehfest, E., Tabeau, A., van Meijl, H., Beltrán, A.M., Kram, T., 2014. Estimating the opportunity costs of reducing carbon dioxide emissions via avoided deforestation, using integrated assessment modelling. Land Use Policy 41, 45-60. doi:10.1016/j.landusepol.2014.04.015

Pellegrini, L., Arsel, M., Falconí, F., Muradian, R., 2014. The demise of a new conservation and development policy? Exploring the tensions of the Yasuní ITT initiative. Extr. Ind. Soc. 1, 284-291. doi:10.1016/j.exis.2014.05.001

Postic, S., 2015. Long-term energy prospective modeling for South America - Application to international climate negotiations. MINES ParisTech / Universidad de Chile, Paris.

Ricci, O., Selosse, S., 2013. Global and regional potential for bioelectricity with carbon capture and storage. Energy Policy, Special Section: Transition Pathways to a Low Carbon Economy 52, 689-698. doi:10.1016/j.enpol.2012.10.027

Riegelhaupt, E., Chalico, T.A., 2009. Opportunities and challenges for biofuel production in Latin America: a forester's perspective. CIFOR.

SAyDS, 2007. Segunda Comunicación Nacional de la República Argentina a la convención Marco de las Naciones Unidas sobre Cambio Climático. Secretaría de Ambiente y Desarrollo Sustentable - República Argentina.

SEAM, 2011. Segunda Comunicación Nacional - Cambio Climático. Secretaria de Ambiente - Presidencia de la República del Paraguay, Asunción.

Sharma, S., Desgain, D., 2014. Understanding NAMA Cycle.

Smeets, E., Faaij, A., Lewandowski, I., Turkenburg, W., 2007. A bottom-up assessment and review of global bioenergy potentials to 2050. Prog. Energy Combust. Sci. 33, 56-106. doi:10.1016/j.pecs.2006.08.001

Smith, P., Bustamante, M., Ahammad, H., Clark, H., Dong, H., Elsiddig, E.A., Haberl, H., Harper, R., House, J., Jafari, M., Masera, O., Mbow, C., Ravindranath, N.H., Rice, C.W., Robledo Abad, C., Romanovskaya, A., Sperling, F., Tubiello, F., 2014. Agriculture, Forestry and Other Land Use (AFOLU), in: Edenhofer, O., Pichs-Madruga, R., Sokona, Y., Faraghani, E., Kadner, S., Seyboth, K., Adler, A., Baum, I., Brunner, S., Eickemeier, P., Kriemann, B., Savolainen, J., Schlömer, S., von Stechow, C., Zwickel, T., Minx, J.C. (Eds.), Climate Change 2014: Mitigation of Climate Change. Contribution of Working Group III to the Fifth Assessment Report of the Intergovernmental Panel on Climate Change. Cambridge, United Kingdom and New York, NY, USA.

Stern, N., 2007. The Economics of Climate Change: The Stern Review. Cambridge University Press.

Syri, S., Lehtilä, A., Ekholm, T., Savolainen, I., Holttinen, H., Peltola, E., 2008. Global energy and emissions scenarios for effective climate change mitigation-Deterministic and stochastic scenarios with the TIAM model. Int. J. Greenh. Gas Control 2, 274-285.

Tanides, C., Beccar, J., Tamborini, L., Acerbi, M., 2006. Escenarios energéticos para la Argentina (2006-2020) con políticas de eficiencia.

UNDESA, 2012. World Population Prospects, the 2012 Revision [WWW Document]. URL http://esa.un.org/unpd/wpp/ASCII-Data/DISK_NAVIGATION_ASCII.htm (accessed 8.20.14).

UNEP, 2012. Global Chemicals outlook 2012 [WWW Document]. URL http://www.unep.org/pdf/GCO_Synthesis\%20Report_CBDTIE_UNEP_September5_2012.pdf (accessed 5.8.14).

US-EIA, 2014. Energy Information Administration - International Energy Statistics.

Vallejo, M.C., Burbano, R., Falconí, F., Larrea, C., 2015. Leaving oil underground in Ecuador: The Yasuní-ITT initiative from a multi-criteria perspective. Ecol. Econ. 109, 175-185. doi:10.1016/j.ecolecon.2014.11.013

van der Zwaan, B.C.C., Calvin, K.V., Clarke, L.E., 2016. Climate Mitigation in Latin America: Implications for Energy and Land Use: Preface to the Special Section on the findings of the CLIMACAP-LAMP project. Energy Econ. 56, 495-498. doi:10.1016/j.eneco.2016.05.005

van Ruijven, B.J., Daenzer, K., Fisher-Vanden, K., Kober, T., Paltsev, S., Beach, R.H., Calderon, S.L., Calvin, K., Labriet, M., Kitous, A., Lucena, A.F.P., van Vuuren, D.P., 2015. Baseline projections for Latin America: base-year assumptions, key drivers and greenhouse emissions. Energy Econ. doi:10.1016/j.eneco.2015.02.003

Veysey, J., Octaviano, C., Calvin, K., Martinez, S.H., Kitous, A., McFarland, J., van der Zwaan, B., 2016. Pathways to Mexico's climate change mitigation targets: A multi-model analysis. Energy Econ. 56, 587-599. doi:10.1016/j.eneco.2015.04.011 
World Nuclear Association, 2008. WNA Nuclear Century Outlook Data [WWW Document]. URL http://www.worldnuclear.org/WNA/Publications/WNA-Reports/nco/Nuclear-Century-Outlook-Data/ (accessed 4.23.14).

World Resources Institute, 2015. CAIT 2.0: WRI's climate data explorer [WWW Document]. World Resour. Inst. URL http://cait2.wri.org/wri?undefined (accessed 3.17.15). 


\section{$1 \quad 7 \quad$ Appendix}

27.1 South American recent contributions to climate negotiations in the framework of the UNFCCC

\begin{tabular}{|c|c|c|}
\hline Country & NAMAs & NDC \\
\hline $\begin{array}{l}\text { Antigua } \quad \& \\
\text { Barbuda }\end{array}$ & 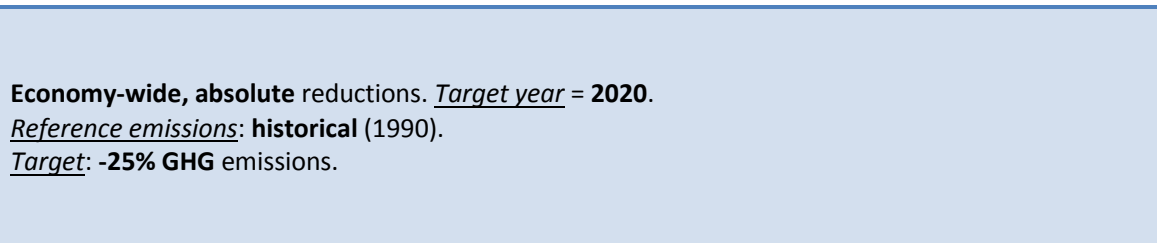 & $\begin{array}{l}\text { Sectorial policies. } \text { Target years }=2020,2030 . \\
\text { Reference indicators: not applicable } \\
\text { Conditional policies: } \\
-\quad \text { Construction of a WTE plant. } \\
-\quad 50 \mathrm{MW} \text { additional RNW ELC capacity (current } \sim 100 \mathrm{MW}) . \\
-\quad \text { Transport efficiency standards. } \\
-\quad \text { Protected Areas Policy. }\end{array}$ \\
\hline Argentina & $\begin{array}{l}\text { No NAMA pledged to the UNFCCC. } \\
\text { National voluntary measures in biofuels, energy efficiency, urban waste, wind energy, national } \\
\text { parks. }\end{array}$ & $\begin{array}{l}\text { Economy-wide, absolute reductions. Target year }=\mathbf{2 0 3 0 .} \\
\text { Reference emissions: national BAU. } \\
\text { Unilateral target: }-\mathbf{- 1 5 \%} \text { GHG emissions. } \\
\text { Conditional target: }-\mathbf{3 0 \%} \text { GHG emissions. }\end{array}$ \\
\hline Barbados & No NAMA pledged to the UNFCCC. & $\begin{array}{l}\text { Economy-wide, absolute reductions. Target year }=2030 . \\
\text { Reference emissions: Historical (2008) } \\
\text { Unilateral target: -23\% GHG emissions }\end{array}$ \\
\hline Belize & No NAMA pledged to the UNFCCC. & 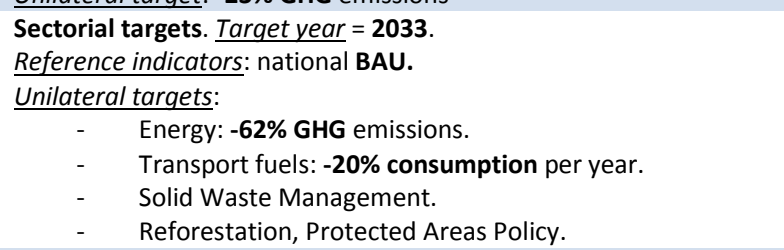 \\
\hline Brazil & $\begin{array}{l}\text { Sectorial targets, with estimated economy-wide results. } \\
\text { Target year }=\mathbf{2 0 2 0 .} \\
\text { Reference emissions: National BAU. } \\
\text { Economy-wide estimate: }-\mathbf{3 8 \%} \text { GHG emissions. }\end{array}$ & $\begin{array}{l}\text { Economy-wide, absolute reductions. } \text { Target year }=\mathbf{2 0 3 0 .} \\
\text { Reference emissions: Historical (2005). } \\
\text { Unilateral target: }-\mathbf{- 4 3} \% \mathrm{GHG} \text { emissions. } \\
\text { Total resulting emissions: } 1,200 \mathrm{MtCO}_{2} \text { eq. }\end{array}$ \\
\hline
\end{tabular}




\begin{tabular}{|c|c|c|}
\hline Country & NAMAs & NDC \\
\hline Chile & $\begin{array}{l}\text { Economy-wide, absolute reductions. } \\
\text { Target year }=\mathbf{2 0 2 0} \text {. } \\
\text { Reference emissions: National BAU. } \\
\text { Target: }-\mathbf{2 0 \%} \text { GHG emissions. }\end{array}$ & 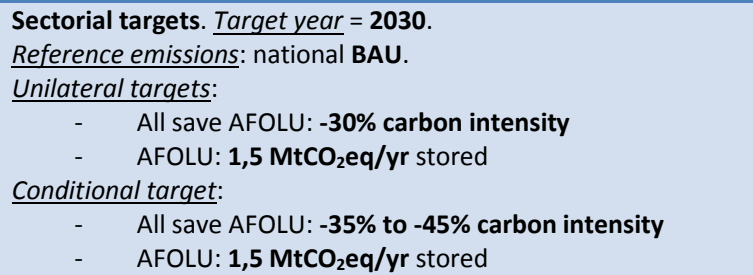 \\
\hline Colombia & $\begin{array}{l}\text { Sectorial targets. } \underline{\text { Target year }}=\mathbf{2 0 2 0 .} \\
\text { Targets: } \\
-\quad 77 \% \text { of electric capacity renewable. } \\
-\quad 20 \% \text { of national fuels bio-sourced. }\end{array}$ & $\begin{array}{l}\text { Economy-wide, absolute reductions. } \text { Target year }=\mathbf{2 0 3 0 .} \\
\text { Reference emissions: national BAU. } \\
\text { Unilateral target: }-\mathbf{2 0 \%} \text { GHG emissions. } \\
\text { Conditional target: }-\mathbf{3 0 \%} \text { GHG emissions. }\end{array}$ \\
\hline Costa Rica & $\begin{array}{l}\text { Economy-wide, absolute reductions. } \text { Target year }=\mathbf{2 0 2 1 .} \\
\text { Reference emissions: historical (2005). } \\
\text { Target: }+\mathbf{0} \% \text { GHG emissions ('carbon neutrality'). }\end{array}$ & $\begin{array}{l}\text { Economy-wide, absolute reductions. } \text { Target year }=2030 . \\
\text { Reference emissions: historical (2012). } \\
\text { Unilateral target: }-\mathbf{2 5 \%} \text { GHG emissions. }\end{array}$ \\
\hline Dominica & $\begin{array}{l}\text { No NAMA pledged to the UNFCCC. } \\
\text { National voluntary strategies to develop geothermal, solar, wind, hydropower. }\end{array}$ & $\begin{array}{l}\text { Economy-wide, absolute reductions. } \text { Target year }=2030 . \\
\text { Reference emissions: } \text { historical (2014). } \\
\text { Unilateral target: }-\mathbf{4} 4.7 \% \text { GHG emissions. }\end{array}$ \\
\hline $\begin{array}{l}\text { Dominican } \\
\text { Republic }\end{array}$ & No NAMA pledged to the UNFCCC. & $\begin{array}{l}\text { Economy-wide, absolute reductions. Target year }=2030 \text {. } \\
\text { Reference emissions: historical (2010). } \\
\text { Conditional target: }-25 \% \text { GHG emissions. }\end{array}$ \\
\hline Ecuador & $\begin{array}{l}\text { No NAMA pledged to the UNFCCC. } \\
\text { National voluntary targets: } \\
\begin{array}{l}-\quad 82 \% \text { oil in primary energy } \\
\end{array}{ }^{14} . \\
-\quad 80 \% \text { of hydropower in national electricity. } \\
-\quad 90 \% \text { renewable Elec. } \\
\text { Target year }=\mathbf{2 0 2 0} .\end{array}$ & 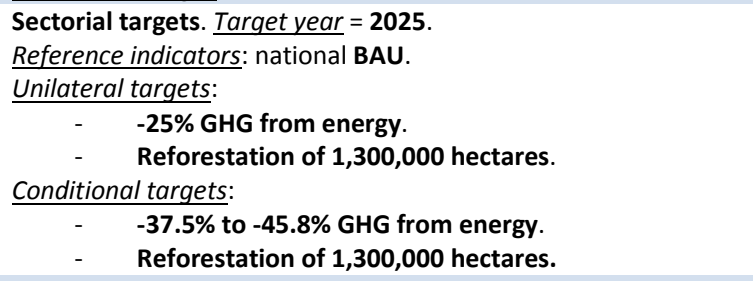 \\
\hline Grenada & No NAMA pledged to the UNFCCC. & $\begin{array}{l}\text { Economy-wide, absolute reductions. } \text { Target year }=2025 . \\
\text { Reference emissions: } \text { historical (2010). } \\
\text { Unilateral target: }-\mathbf{3 0 \%} \text { GHG emissions. } \\
\text { Indicative target: }-\mathbf{4 0 \%} \text { GHG emissions by } 2030 .\end{array}$ \\
\hline Guatemala & No NAMA pledged to the UNFCCC. & $\begin{array}{l}\text { Economy-wide, absolute reductions. } \text { Target year }=\mathbf{2 0 3 0 .} \\
\text { Reference emissions: } \text { national BAU. } \\
\text { Unilateral target: }-\mathbf{1 1 . 2 \%} \text { GHG emissions. } \\
\text { Conditional target: }-\mathbf{2 2 . 6 \%} \text { GHG emissions. }\end{array}$ \\
\hline Guyana & No NAMA pledged to the UNFCCC. & $\begin{array}{l}\text { Sectorial targets. Target year }=2025 . \\
\text { No reference emissions. } \\
\text { Conditional targets: } \\
\begin{array}{c}-\quad \text { Forestry: net removal of } 52 \mathrm{MtCO} \\
-\quad \text { eq/yr. }\end{array} \\
\quad \text { Energy: } 20 \% \text { renewable electricity in national supply. }\end{array}$ \\
\hline Haiti & No NAMA pledged to the UNFCCC. & $\begin{array}{l}\text { Sectorial, absolute reductions. Target year }=\mathbf{2 0 3 0} \text {. } \\
\text { Reference emissions: national BAU. } \\
\text { Unilateral target: }-\mathbf{5 \%} \text { GHG emissions in energy, AFOLU, waste } \\
\text { Conditional target: }-\mathbf{2 5 \%} \text { GHG emissions in energy, AFOLU, waste }\end{array}$ \\
\hline
\end{tabular}

\footnotetext{
${ }^{14}$ Down from $92 \%$ in 2010
} 


\begin{tabular}{|c|c|c|}
\hline Country & NAMAs & NDC \\
\hline Honduras & No NAMA pledged to the UNFCCC. & $\begin{array}{l}\text { Sectorial, absolute reductions. } \text { Target year }=\mathbf{2 0 3 0 .} \\
\text { Reference emissions: national BAU. } \\
\text { Unilateral targets: } \\
\begin{array}{c}-\quad \mathbf{1 5 \%} \text { GHG emissions in energy, industry, AFOLU, waste. } \\
-\quad \text { Reforestation of } 1 \text { million hectares. }\end{array}\end{array}$ \\
\hline Panama & No NAMA pledged to the UNFCCC. & $\begin{array}{l}\text { Sectorial targets. } \text { Target year }=\mathbf{2 0 5 0} \text {. } \\
\text { Reference: } 2014 \text { for energy, BAU for AFOLU. } \\
\text { Unilateral targets: } \\
\begin{aligned}-\quad+30 \% \text { renewable electricity capacity by } 2050 \\
-\quad+\mathbf{1 0 \%} \text { GHG absorption by forest sinks }\end{aligned} \\
\text { Conditional target: } \\
\quad+\mathbf{8 0 \%} \text { GHG absorption by forest sinks. }\end{array}$ \\
\hline Paraguay & $\begin{array}{l}\text { No NAMA pledged to the UNFCCC. } \\
\text { National voluntary targets in reforestation. }\end{array}$ & $\begin{array}{l}\text { Economy-wide, absolute reductions. Target year }=\mathbf{2 0 3 0 .} \\
\text { Reference emissions: } \text { national BAU. } \\
\text { Unilateral target: }-10 \% \text { GHG emissions. } \\
\text { Conditional target: }-20 \% \text { GHG emissions. }\end{array}$ \\
\hline Peru & $\begin{array}{l}\text { Sectorial targets. } \text { Target year }=2021 . \\
\text { Targets: } \\
\begin{array}{cl}- & 0 \% \text { net deforestation. } \\
- & 33 \% \text { of final energy from renewables. }\end{array}\end{array}$ & $\begin{array}{l}\text { Economy-wide, absolute reductions. Target year }=\mathbf{2 0 3 0 .} \\
\text { Reference emissions: } \text { national BAU (updatable until 2020). } \\
\text { Unilateral target: }-\mathbf{2 0 \%} \text { GHG emissions. } \\
\text { Conditional target: }-\mathbf{3 0 \%} \text { GHG emissions. }\end{array}$ \\
\hline $\begin{array}{l}\text { Trinidad and } \\
\text { Tobago }\end{array}$ & No NAMA pledged to the UNFCCC. & $\begin{array}{l}\text { Economy-wide, absolute reductions. Target year }=\mathbf{2 0 3 0 .} \\
\text { Reference emissions: national BAU. } \\
\text { Conditional target: }-15 \% \text { GHG emissions. }\end{array}$ \\
\hline Suriname & No NAMA pledged to the UNFCCC. & 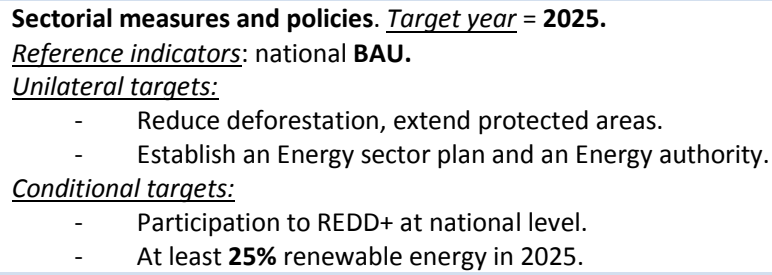 \\
\hline Uruguay $^{15}$ & $\begin{array}{l}\text { No NAMA pledged to the UNFCCC. } \\
\begin{array}{cl}\text { Voluntary actions in National Plan } 2015: \\
- & 300 \mathrm{MW} \text { additional wind. } \\
- & 200 \mathrm{MW} \text { additional biomass. } \\
- & 50 \mathrm{MW} \text { additional small hydro. } \\
- & 15 \% \text { of electricity from non-hydro renewables } \\
- & 30 \% \text { of waste used for Elec. }\end{array}\end{array}$ & 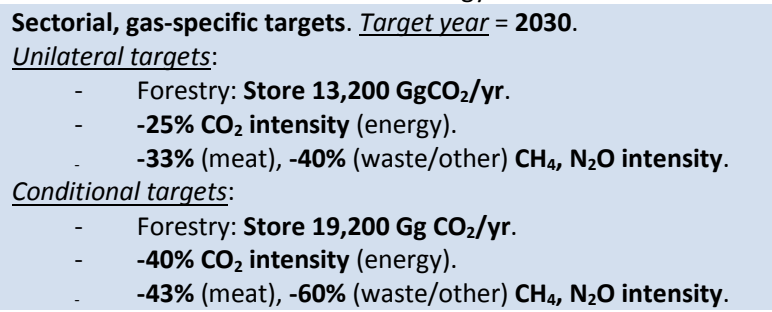 \\
\hline Venezuela & No NAMA pledged to the UNFCCC. & $\begin{array}{l}\text { Economy-wide, absolute reductions. Target year }=2030 . \\
\text { Reference emissions: national BAU. } \\
\text { Conditional target: }-\mathbf{2 0 \%} \mathrm{GHG} \text { emissions. }\end{array}$ \\
\hline
\end{tabular}

\footnotetext{
${ }^{15}$ Uruguay's NDC is simplified here for readability. The full contribution can be found on UNFCCC's portal.
} 
Page 1 